\title{
Study for Odilon Redon in the Perspective of the Unconscious: Centering on before His Black Series
}

\author{
Hyun Kwon Lee ${ }^{1}$ and Hye Ri Yoon ${ }^{2}$ \\ ${ }^{1}$ Hyun Kwon Lee Psychoanalytic Office, Seoul, Korea \\ ${ }^{2}$ Hye Ri Yoon Psychiatric Clinic, Seoul, Korea
}

\author{
무의식적 관점에서 본 화가 오딜롱 르동: 그의 검은색 회화 이전 작품을 중심으로 \\ 이현권 ${ }^{1} \cdot$ 윤혜리 ${ }^{2}$ \\ 이현권 정신분석 연구소, ${ }^{1}$ 윤혜리 정신건강의학과의원 ${ }^{2}$
}

Odilon Redon (1840-1916) was a painter who represented French symbolism in Western modern painting. Redon's black is not simply an expression of depression and anger of 'the abandoned child.' The author explained that the libidinal satisfaction of his idealized mother object and dependence on father, and the Oedipus conflict by ambivalent emotion with these two important objects were expressed as a result of a compromise in his painting, and through this process, the unconscious fantasies-individual narratives-played an important role in his black formation. Based on this analysis, the author insisted that paintings of Western art history changed from the era of ideational space to individual space during the Redon time. This study suggests that the unconscious perspective plays a meaningful role in art history and an important frame of understanding arts that expands the boundaries of the whole human being indefinitely.

Psychoanalysis 2021;32(3):89-106

KEY WORDS: Odilon Redon · The unconscious · Black (noir) · Individual space.

Received: April 17, 2021 Accepted: May 11, 2021

Address for correspondence: Hyun Kwon Lee, MD

Hyun Kwon Lee Psychoanalytic Office, 27 Guuigangbyeon-ro, Gwangjin-gu, Seoul 05115, Korea

Tel: +82-2-2138-7588, Fax: +82-2-2138-7589, E-mail: treeself@hanmail.net

서 론

오딜롱 르동(Odilon Redon 1840 1916)은 근대 회화에서 프 랑스 상징주의를 대표하는 화가이다. 그는 당시 인상주의 등 의 주류 회화 흐름에서 벗어나 인간의 마음에 관심을 가지면 서 쉽게 이해할 수 없는 이미지로 주목을 받았었다(Figure 1). 회화의 운동이 인간의 내면을 향해 본격적으로 접근했던 시기는 신고전주의 회화에 반발한 낭만주의이다. 1789년 프랑 스 대혁명은 시대를 지배했던 이성의 체계에 깊은 의심을 던 지게 되었고, 이 흐름을 받은 시대적 사조가 바로 낭만주의인 것이다. 이성의 환상과 신뢰에 대한 균열은 유럽 사회 전반을 흔들게 되었고, 그 대안으로 인간의 상상력과 영감, 감정 등을

This is an Open Access article distributed under the terms of the Creative Commons Attribution Non-Commercial License (https://creativecommons.org/licenses/by-nc/4.0) which permits unrestricted non-commercial use, distribution, and reproduction in any medium, provided the original work is properly cited.
중시하게 되었다. 르동의 작품은 바로 이러한 흐름에서 꽃을 피웠지만 회화 운동에서 비롯된 것이 아니라, 바로 프랑스 내 에서 일어난 시나 소설 등 상징주의 문학 사조의 일부로서, 또 는 그것을 설명하는 시각적 표현으로서 인정을 받았다. 따라 서 그를 포함한 상징주의 회화는 좁은 의미로는 문학과 함께 한 프랑스 내의 국지적 상징주의로 이해가 되었으며, 르동의 작품 역시 미술사의 흐름 속에 작품 자체로 평가받기보다 문 학과 연결된 삽화로 여겨지기도 하였다(Kim 2002). 따라서 르 동을 상징주의 화가, 또는 문학에서 독립한 조형적 요소로서 미술사가들이 종합적으로 다룬 것은 비교적 최근이다. ${ }^{a}$ 특히

a서양미술사 학계가 상징주의 회화 및 르동의 작품에 관심을 두기 시 작한 것은 1960년, 1970년부터이고 이로써 르동에 대한 관심은 커졌 지만, 역시 이 시기의 연구는 문학과 연결된 르동이었다(Han 1995). 1994, 1995년 시카고와 런던, 암스테르담 등의 전시를 위해 Druick (Douglas W. Druick) 등에 의해 르동에 대하여 통합적인 미술사적 관점에서 연구를 시행하였다. 


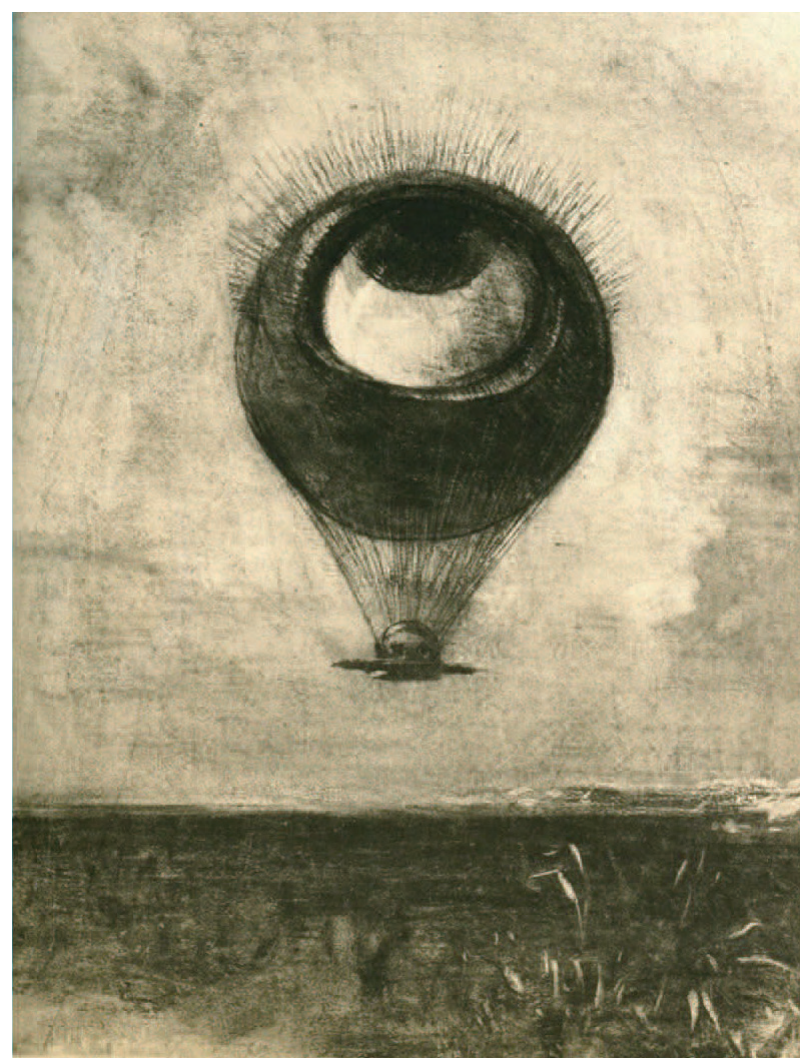

Figure 1. Eye-Balloon (1878), Charcoal, $42.2 * 33.2 \mathrm{~cm}$, The Museum of Modern Art.

그에 대한 회화 연구의 관심은 대략적으로 분류하면 두 흐름 에서 파생되는 듯하다. 하나는 그가 20 30여 년간 전념했던 'noir(검은색)'와 1890년부터 그 검은색을 포기한 이유 및 색 채 시기에 대한 연구이다.

태어난 후 11 여 년 동안 부모와 대부분의 시간을 함께 하 지 못했던 르동의 불행한 과거와 그가 반복적으로 말했던 그의 우울한 심리는 그의 검은색 및 색채로의 변화를 이해 하는 데 있어 대부분의 논문이나 서적에서 유력한 근거로 제시되었다. 이러한 접근들은 주로 의식적인 면에서의 상황, 심리, 대상들과의 관계를 통해 연구되었고 여러 의미 있는 설명을 하였다. 이를 토대로 르동의 무의식에 관심을 가지고 과감하게 접근하기도 하였는데, Druick 등(1994)은 하나의 중요한 가설로서 프로이트의 '가족 로망스(family romance)' 를 적용시켰다. 또한 정신분석적 접근 역시 Wilson(1982)에 의해 제시되었는데, 그는 예술가인 두 명의 환자의 분석 경험 을 토대로 르동의 검은색 및 색채로의 변화를 분석하였다. 그 는 르동이 색채를 제한한 이유를 통합되지 않은 분노나 폭 력성, 죽음에 관련된 소망으로 이해를 했고, 검은색에서 색 채로의 변화의 이유를 그의 스승인 브레댕(Rodolphe Bres$\operatorname{din})$ 의 죽음과 연관시켰다.
위 발표된 정신분석적인 관점을 포함한 르동에 대한 다각 도의 설명은 그의 회화를 이해하는 데 도움이 된다. 하지만 그의 이미지와 글을 보면 앞선 글로서는 설명하기 어려운 의문점이 있다. 우선 르동이 1867년에 검은 색에 대하여 적 은 글을 보면 다음과 같다(Warner 2017).

\section{〈인용문 1〉}

검은색은 모든 색채 중에서 가장 본질적인 색이다. 무엇보다도 검은색은 깊고 은밀한 몸과 마음의 근원으로부터 흥분(excitement)과 생명력(vitality)을 이끈다 $\cdots$ 누구든 검정을 존경해야 한 다. 그 어떤 것도 검정을 더럽힐 수 없다(prostitute) $\cdots$

그의 고향(Peyrelebade)은 부모로부터 버림을 받았던 고통 의 공간이자, 그의 삶 전반을 지배했던 슬픔과 우울의 장소였 고 그 감정들이 연결된 검은 색의 공간이었다(Druick 등 1994). 하지만 그는 그 '고통의 공간'에 매년 방문하려는 모순적인 모습을 보였고, 그 땅이 가족에 의해 팔리자 그가 20여 년간 몰입해서 그려왔던 검은색을 포기하게 된다(Bacou 1987). 또 한 위 〈인용문 1〉에서 르동은 검은색을 우울과 분노가 아닌 본 질적인 색으로 최상의 가치에 두었으며, 특히 검은색에서 흥 분과 생명력을 느꼈다고 말한다. 이에 상응하여 그가 그렸던 검은 공간에서의 모습들은 단순히 무겁지만은 않다. 그의 검 은색 그림 연작은 전반적인 우울의 그림자가 있지만 어떤 그 림에서는 어린 아이와 같은 천진난만함과 생기가 느껴진다.

위 내용들을 종합해볼 때 그의 검은색은 우울함과 분노만 으로 설명되지 않은 다른 내용이 내포될 가능성을 짐작하게 하며, 여기에 무의식적 관점이 의미 있는 설명을 할 가능성 이 있는 것이다. 본 논문은 이를 밝히기 위해 르동이 검은 시 기로 가기 전까지의 회화를 분석함으로 르동에게 검은 색이 어떤 의미가 있는지 무의식적 관점으로 설명할 것이다. 이를 위한 저자의 가설은 다음과 같다.

르동에게 검은색은 그의 고향인 페일레버드를 의미하며, 그 공 간은 그의 주요 대상과의 무의식적 환상으로 채워져 있다.

분석의 기본적인 틀은 프로이트가 무의식적 관점으로 다빈 치를 분석했던 병적학적인(pathography) 관점이고(Freud 1910), 각각의 필요에 따라 임상에서 경험되는 구조 모델 (structural model) 및 대상 관계의 이론이 적용될 것이다. 저자 가 모더니즘 회화 변화를 위해 제시해왔던 틀을 적용할 것이며 (Table 1), 본 논문은 르동의 회화를 꿈의 발현몽, 또는 백일몽 처럼 이해하여 그 층 아래 흐르는 잠재몽을 분석함으로 개별적 인 내러티브가 그의 회화에 어떤 영향을 주는지 분석할 것이 
Table 1. Change of modern art in the perspective the unconscious

\begin{tabular}{lll}
\hline & \multicolumn{1}{c}{ Art of eras } & \multicolumn{1}{c}{ Modern to contemporary art } \\
\hline Story (narrative) & Narratives of eras & Individual story or narrative. esp. unconscious fantasy \\
Space, object & Space and object of the eras & Individual space and object. esp. unconscious space and objects \\
Art style & Style of the eras & Individual style \\
Time & From the past & From the present \\
\hline
\end{tabular}

다. 또한 이러한 개별적인 내러티브-무의식적 환상-가 그의 양식과 회화 공간을 어떻게 결정하는지 설명할 것이다. 이를 위해 중요한 가정은 르동의 회화 형성에서 꿈이나 백일몽이 깊 은 영향을 준다는 것이다. 이는 그의 회화 전 과정의 분석을 통 해 밝혀질 것인데, Gibson(2017)은 이에 대하여 르동의 회상들 이 시사하는 바는 백일몽(daydream)으로 그의 시간들을 보낸 다는 점을 말하였다. 특히 그의 검은색 회화의 첫 작품이 '꿈속 에서'(Dans il Reve)라는 점은 의미하는 바가 크다.

논문 분석 자료는 르동의 삶과 회화를 미술사나 미학적인 관점에서 분석한 서적들과(Druick 등 1994; Bacou 1987; Gibson 2017), 저자가 보기에 의미 있는 르동 관련 논문들 (Kim 2002; Han 1995)을 참고하였다. 특히 Druick 등(1994) 의 저서는 몇몇 미술사가들의 글과 함께 르동의 회화와 삶 을 심도 있게 종합적으로 적은 책으로 본 논문에 많은 도움 을 주었다. 또한 르동이 적은 글을 모아 놓은 서적과(Redon 1986) 그의 많은 이미지들이 분석에 중요한 토대가 되었다.

\section{본 문}

본문은 르동의 검은색의 형성과정에 무의식이 어떤 역할 을 할 수 있는지에 대하여 알아볼 것이다. 이를 위해 우선 르 동의 삶과 그의 회화를 개략적으로 살펴본 후, 그의 삶에서 noir라 불리는 검은색 시대로 가기 전(1840 1878)까지의 삶 과 무의식적 환상, 회화의 관계를 분석할 것이다.

\section{르동의 삶}

르동은 1840년 프랑스 포도주 산지로 유명한 보르도 (Bordeaux)에서 아버지 베르트랑 르동(Bertrant Redon, 1798 1874)과 어머니 마리 오딜 게랑(Marie Odile Guerin, 1820 1909) 사이에서 오 남매 중 둘째 아들로 태어났다. 프 랑스 보르도 출신인 아버지는 가정 형편이 기울자 미국으로 건너가 경제적으로 성공하였고, 그곳에서 크레올 $(\text { Creole })^{\mathrm{b}}$ 인 아내를 만나 결혼하였다. 아버지는 르동을 임신한 부인, 첫 째 아들인 어네스트(Felix Ernest)와 함께 프랑스로 귀국하 였다. 르동의 아버지는 배를 타고 프랑스로 오는 이 장면을 르동에게 종종 이야기하였다고 한다. 르동은 태어난 지 이틀 만에 가족과 떨어져 페일레버드(Peyelabade)로 보내졌고,
르동이 11 세가 되어 가족이 살고 있는 보르도로 가게 된다. 페일레버드에는 나이든 외삼촌이 관리하고 있던 르동의 아 버지 소유의 땅과 집이 있었다. 르동이 가족과 떨어진 이유 에 대하여 어머니 젖이 안나왔다거나 예민한 어머니가 르동 을 보기 싫어했다는 등의 다양한 의견이 있지만, 미술사가들 은 르동의 건강이 안 좋아서 보내어졌다는 설명이 가장 설 득력이 있다고 이야기한다. ${ }^{c}$ 광활한 대지에 가족과 떨어져 외로움과 슬픔 속에 보낸 르동의 어린 시절은 이후 그의 정 서 및 예술에 깊은 영향을 끼치게 된다.

11 세에 르동은 가족에게 돌아갔고 늦은 교육에 잘 적응을 못 하여 힘든 시절로 기억을 하게 되나 음악과 미술에는 흥 미가 있었다. 15세에 본격적으로 지역 화가인 고랭(Stanislas Gorin)으로부터 미술 교육을 받는다. 고랭은 르동에게 예술 의 문을 열게 해준 첫 번째 스승이다. 고랭의 기존 수업 방식 에서 벗어나 시적인 감수성을 통해 르동을 가르쳤고, 르동은 그것에 반응하여 예술에 더욱 열중하게 된다. 17세에 르동은 아버지의 뜻에 따라 건축가가 되는 수업을 들었으나, 그는 미 술학교에 가기 위한 준비로 생각한다. 이 시기 건축 수업은 그 의 상상력에 사실적인 논리를 부여하였다. 이 시기에 르동에 게 두 번째로 영향력을 주는 식물학자 클라보(Armand Clavaud)를 만난다. 클라보는 르동에게 동시대의 과학과 문학을 알려주고 현미경에 비친 미생물의 세계를 보여주었다. 이를 통해 르동은 인간의 시각을 넘어서는 초자연적인 존재를 인 식하게 된다. 20 대 초반에 르동은 파리 국립미술학교 건축과 b원래는 신대륙에서 태어난 순수 에스파냐인에 한정되었으나, 북아 프리카-라틴 아메리카-서인도 제도에서 태어난 에스파냐인과 프랑 스인, 이들과 신대륙의 흑인 사이에서 태어난 사람들을 일컫는 말로 의미가 확대되었다. 지금은 미국 루이지애나주에 정착한 위 사람들 을 가리키는 경우가 많다. 르동의 회화에서 자신의 모습을 흑인 또 는 혼혈인으로 동일시하는 경우가 많았으며 이는 무의식적으로 어 머니에 대한 억압된 모습에 대한 동일시로 이해된다.

'최근의 연구에서 르동이 가족과 분리된 가장 유력한 이유는 그가 뇌 전증(epilepsy)를 않았기 때문이라고 하며, 당시에는 휴양지에 주로 보냈다고 한다. 그의 자서전적인 글에서도 비슷한 설명이 있다. 저자 의 생각으로는 아마도 어린 나이에 일어난 열성 경련(febrile convulsion)으로 추측이 되고, 이러한 빈번한 경련을 통해 어린 르동은 심한 불안과 공포를 느꼈을 것이다. 또한 사회적으로도 뇌전증은 심각한 오명(stigma)의 분위기가 있어 상위 계층에서 뇌전증 증상이 있으면 그 질환을 숨겼다고 한다(Druick 등 1994). 
를 지원했으나 구술시험에서 떨어지게 된다. 1864년 아버지 의 권유로 파리의 제롬에게 그림을 배웠는데 학업 과정에서 고통스러운 경험을 하게 된다. 그는 결국 수개월 만에 중퇴 를 하고 보르도에 오게 되는데, 거기서 세 번째 스승인 동판 화가 브레댕을 만난다. 그는 르동에게 동판화(etching) 및 석 판화(lithography)를 가르쳤으며, 뒤러나 램브란트의 판화 작 품을 소개한다. 이 시기 이후 르동은 석판화와 목판화, 목탄화 (charcoal drawing)에 주력하게 된다.

1870년 7월 보불 전쟁이 일어나 10 월에 징집이 되는데, 병 약했던 르동이 그의 형제 중 유일하게 참전하게 되었고 그 참 전 소식이 보르도 지역지에 나오게 된다. 이 경험은 르동에게 삶의 전환점이 되며, 르동의 회화에도 영향을 주게 된다.

1872년에 르동은 파리에서 레이삭 부인의 문학 살롱에 출 입을 하게 되고 많은 문인과 화가와 교류한다. 1874년은 르동 에게 중요한 시기로 그의 부인이 될 카미유 팔트(Camille Falte)를 만난다. 이 시기 아버지 베르트랑이 사망한다. 이 두 사건은 르동의 심리와 회화에 깊은 영향을 준다.

1879 부터 르동은 검은 공간에서 '나'를 본격적으로 표현을 한다. 1879년에 르동은 첫 석판화집인 '꿈속에서(Dans il Reve')'를 제작하여 판매를 한다. 1880년 르동은 예술을 이해 하고 밝은 성격의 카미유와 결혼을 하고, 예술에 몰입하게 되면서 1881,1882 년에 개인전을 하였다. 반응은 좋지 않았 지만 기자 겸 번역가인 안느캥과 소설가 위스망를 알게 되 어 그의 작품을 알리게 된다. 이 시기 두 번째 석판화 '에드가 앨런 포우에게 바친다'를 제작하였고, 1883년 세 번째 석판화 '기원(Les Origin)'을 출판한다. 르동은 열정적인 작업과 출 판을 하였다. 1884년에는 신인상주의 운동을 이끌게 되는 점묘파 화가들과 '독립예술가협회'를 창립하면서 초대 회장 을 하게 되었다. 르동은 많은 전시를 통해 자신을 알렸으며 계속 자신에게 영감을 주는 소설이나 시를 통해 자신의 작업 을 한다. 프랑스의 소설가 플로베르의 소설 '성 안투안의 유 혹'은 그에게 많은 영감을 제공하여 1888년부터 3회, 42점의 관련 삽화집을 내게 된다. 이는 르동이 남긴 판화 수의 5 분의 1 이나 되는 양이다. 르동은 점차 후배 화가들에게 존경을 받 게 되었는데, 고갱을 추종하는 나비파의 젊은 화가들에게 상 징주의의 지도자로 인정을 받는다.

1886년 첫 아이는 출산 몇 개월 뒤 사망하였으나 1899년 에 둘째 아이 아리(Ari Redon)가 태어났고, 이는 르동에게 심리적으로 영향을 준다. 1890 년 그의 스승이었던 클라보가 자살을 하여 르동은 큰 충격에 빠지게 된다. 이러한 일련의 삶의 변화를 겪은 후 르동은 작품에 색채를 사용하기 시작하 게 된다. 르동은 매년 여름에 페일레버드에서 지냈으나 1897 년 그 농장이 형과 어머니에 의해 매각되어 분노한다. 마음
의 고향이었던 그 공간의 매각은 르동에게 검은색과 멀어지 게 했으며, 점점 더 색채 사용의 길로 가게 한다. 1899년 그 의 마지막 석판화인 '요한 묵시록'를 출판하고, 이후 그의 주 요 테마가 될 꽃병에 꽃을 그리기 시작한다. 르동은 이후 공 식적으로 검은색을 사용하지 않는다. 이 시기의 그림들은 과 거의 테마를 현재의 색채를 입히거나 과거 소설이나 시에서 의 영감보다 신화를 통해 자신의 이야기를 표현한다. 또한 새롭게 반복적으로 그린 주제는 꽃병과 꽃이다. 내면의 갈등 과 결핍은 그의 이 시기 그림을 통해 승화가 되는 듯하다. 실 제 그는 그의 어머니가 1908년 사망하기 전에 극적인 화해 를 한다. 그가 Gabriel Frizeau에게 보낸 편지에서 "나는 내 가 어머니를 다시 보았을 때 만큼 나의 어머니를 사랑했을 때가 없었다. 마치 나는 어린 아이가 된 듯했고 어머니와 감 정적인 연결을 느꼈다.”라고 적었다(Druick 등 1994).

\section{르동의 삶과 검은색 회화의 형성과정에 대한 분석}

\section{8년의 한 그림(Figure1)}

이상한 그림이다. 안구 모양의 기구가 잘려진 머리를 어디 로 옮기고 있는 듯하다. 긴 눈썹이 눈에 붙어있고, 눈은 하늘 을 향해 있다. 아래는 황량한 검은 들판이다. 여러 가지 의문 이 든다. 우선 하늘을 향한 눈 모양의 애드벌룬, 잘려진 머리 는 무엇을 의미할까? 또한 왜 이 기괴한 풍선은 머리를 (왜, 어디로)옮기고 있을까? 그 아래 황량한 검은 들판은 무엇일 까? 이러한 의문들은 이 그림을 그린 후 르동의 변화로 커진 다. 이 그림을 그린 후 '검은 시대'가 본격적으로 시작된 것이 다. 즉 그는 이 그림 이후 검은색을 이용하여 '나'를 적극적으 로 표현했고, 이를 대중에게 발표했던 것이다.

앞서 언급했듯이 검은색의 사용에 대해 학자들은 여러 이 유들을 제시하였고 대부분 타당하다. 하지만 〈인용문 1〉에서 의 의문인 르동이 (우울함을 표상하는)검은색에서 흥분과 생 명력을 느낀 것과 그가 고통의 공간이라고 말했던 페일레버 드를 정기적으로 방문했으며, 그 장소가 팔렸을 때 검은색을 포기했다는 점들은 추가적인 설명이 필요할 듯하다. 저자는 논리적으로 이해할 수 없는 르동의 모습에 대하여 무의식적 관점으로 그의 검은색을 설명할 수 있다고 말했었다. 따라서 앞으로의 내용은 '무의식적 관점에서 본 르동의 검은색의 형 성과정'에 대한 분석으로 연결된다.

\section{버려진 아이}

1964/5년에 그린 Figure 2에서 발가벗은 아이가 들판에서 쫓겨난 듯 손으로 얼굴을 가리고 달려가고 있다. 그는 황량 한 들판에 있다. 주변에 아무도 없다. 배제당하고 버려진 듯 


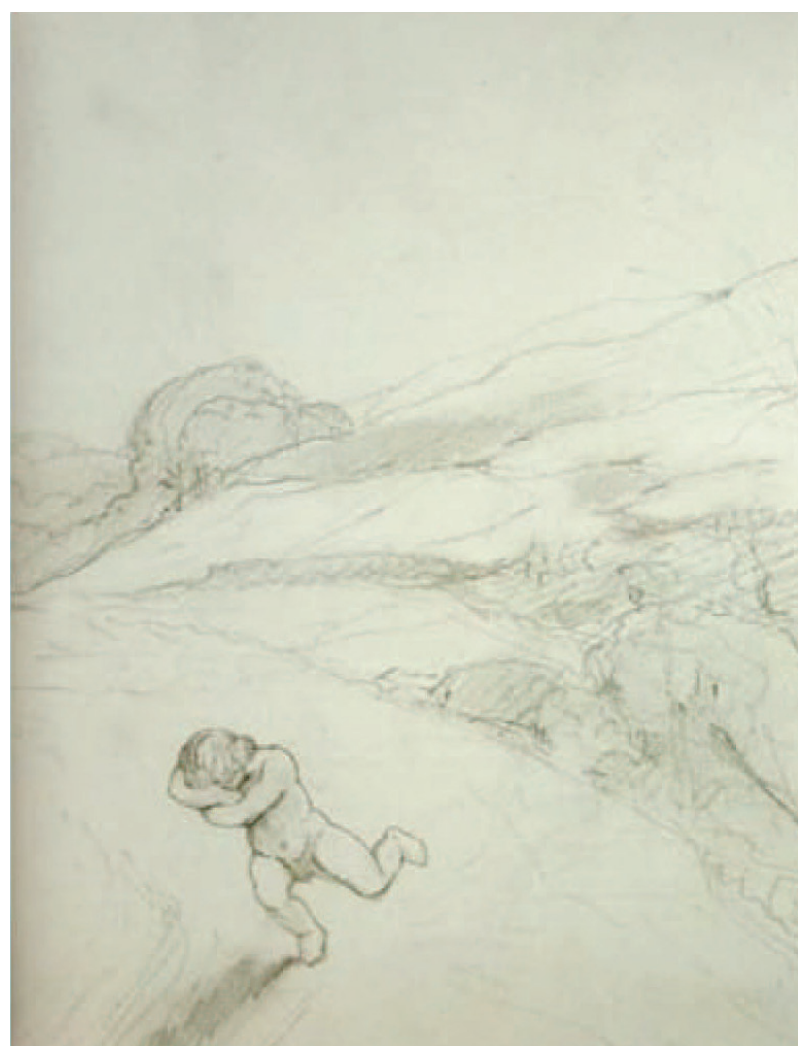

Figure 2. Child Running in a Lsandscape (1864/65), Graphite, 23* $15 \mathrm{~cm}$, Musee du Louvre.

슬픔과 외로움, 분노, 불안의 복합적인 감정이 느껴진다.

이 그림은 르동이 화가 제롬에게 배우는 기간에 그린 그림 이다. 앞서 잠시 말했듯 제롬에게 배웠던 기간은 억압적인 교 육 방식에 무기력함과 고통을 받은 불행한 시간이었다. 그는 이 시간을 11 년간 가족에게 소외되었던 고통스러운 어린 시 절과 유사하게 느끼는 듯하다. 자신의 내면 세계를 타인의 글 과 반응하여 그림을 그렸던 그는, 역사학자인 Jules Michelet 의 아래 글을 보고 위 그림을 그렸다고 한다(Druick 등 1994).

\section{〈인용문 2〉}

...(세 번째 아이인)그 아이는 그녀(어머니)의 발 아래에 떨어져 있다 $\cdots$ 아이는 무척 마르고 몸에 여러 개의 멍이 있다 $\cdots$ 아이는 피곤함과 졸음에 힘들어하며 바위 위로 몸을 던졌다. 그녀의 두 개의 팔은 두 아이밖에 감당할 수가 없다 $\cdots$

11 년 넘게 가족과 떨어져 지냈던 그의 유년 시절의 상처는 위 글과 같이 어머니의 품에서 버려진 아이로 그의 삶에 지 속적인 영향을 준다. ${ }^{d}$ 우울과 고통의 시간은 그의 회화 전반,

d이 부분은 르동의 글에서 반복적으로 언급이 된다. 특히 그가 50대 가 넘어서 색채의 시대의 기간에도 그를 가족에서 '소외된 자'로 자 신을 말하였다(Druick 등 1994).
즉 검은색과 색채의 시대와 직접적으로 영향을 준다. 하지만 이 지점에서 정신분석적인 경험이 도움이 될 만한 흥미로운 현상이 있다. 바로 르동이 보였던 그 기간에 대한 기억 착오 이다. 르동은 분명 그의 아들에게 그 시간을 "버려진, 가족들 과 아주 떨어진, 그 어떤 애정이 없는”이라 표현하였고, 1895 년 자서전적인 글에서 그가 기억하는 어릴 적 기억은 여름에 그의 형이 피아노로 페일레버드의 침묵을 깨웠다는 이야기 뿐 다른 가족이 모였다고 언급한 적이 없었다(Redon 1986; Druick 등 1994). 마치 가족들과 접촉이 없는 듯하지만 미술 사학자들의 연구는 좀 다르다. 르동은 종종 가족들이 있는 보르도로 갔었고, 매년 여름마다 가족들은 페일레버드에서 보냈다고 한다. 또한 7세에 르동은 가족들과 파리에서 1년간 체류한 기간에 대해 르동은 나이든 하인과 미술관을 방문한 것만을 기억하였다(Druick 등 1994).

이러한 현상들에 대하여 지금 언급할 수 있는 무의식적 설명은 다음과 같다. 첫째, 위 기억의 착오와 선택적 기억은 분명 정신분석적 경험에서 신경증적인 반응으로 그의 주요 대상과의 무의식적 역동이 그의 삶에 영향을 주었을 거라 짐 작하게 된다. 둘째, 무의식적 여러 층위의 갈등이 예상되는 르동의 무의식적 역동의 전면에서 가장 영향력 있는 자기 표상(self representation)은 ‘버려진 아이’라는 것이다.

\section{어머니 대상}

그는 그의 실제 어머니를 그린 적이 없다. 이는 그의 주변 사람이나 부인에 대한 초상화를 반복적으로 그렸던 것과 비 교된다. 실제 르동의 어머니에 대한 평들은 그리 좋지 않다. 르동 역시 그의 어머니에 대하여 '지적인 능력이나 견고한 성격을 가지지 않은 경박한(frivolous)' 사람이라고 하였다. 그녀는 그의 남편보다 그의 첫째 아들에게 평생 집착하였다 (Druick 등 1994).

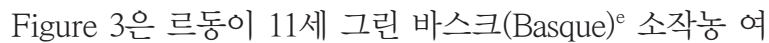
인이다. 르동이 그린 첫 그림으로 알려져 있고, 이 그림으로 학교 생활에서 상을 받아 즐거웠던 기억으로 남았다고 한다. 르동에게 바스크 사람과 지역은 특별한 의미가 있다. 저자의 짐작은 Figure 3의 바스크 여인은 르동의 억압된 '이상화된 어머니 대상'의 변형된 형태이다. 이에 대한 몇 가지 근거는

${ }^{\mathrm{e}}$ 바스크 지역은 피레네 산맥을 가운데 두고 프랑스와 스페인 접경에 위치해있고 현재는 스페인에서 자치권을 가지고 있다. 하지만 바스 크인들은 그들의 언어를 가지고 있고 프랑스인이나 에스파냐인과 는 다른 특징을 가지고 있는데, 눈썹이 짙고 강한 턱을 가지고 있으 며 용감하고 모험을 좋아한다고 알려져 있다. 1937년 스페인 내전 이후 자치권을 스페인 정부에게 상실되었으나 지속적인 독립을 주 장하였다. 


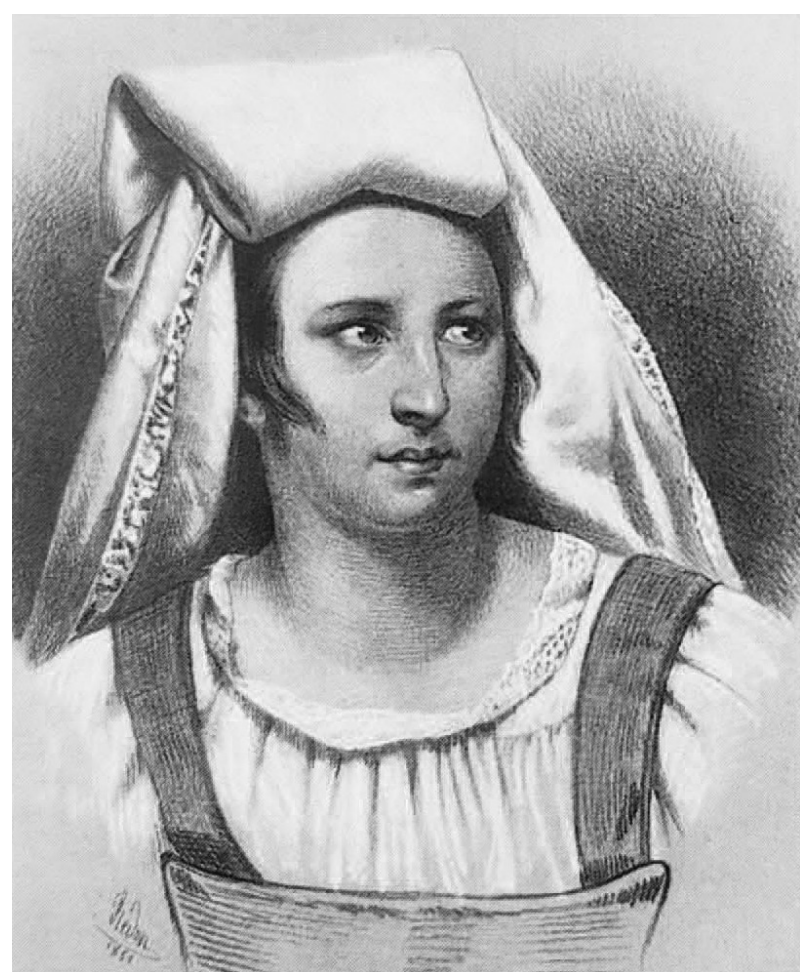

Figure 3. Basque Peasant Girl (1851), Black and white chalk, 37.7* $29.4 \mathrm{~cm}$, Musee du Louvre.

다음과 같다. 첫째, 20대 초반 건축가가 되기 위한 구술 시험 에서 떨어졌을 때, 그가 찾은 곳이 그에게 '원시적 아름다움' 및 '은밀한 애착'이 느껴지는 바스크 지역이었다(Druick 등 1994). 당시 르동이 자신감 상실과 우울감을 호소했다는 점은 시사하는 바가 있다. 루소가 정글에서 그의 고통스러운 삶의 도피처인 어머니 대상을 추구했던 것처럼(Lee와 Yoon 2021), 그는 바스크 지역에서 위로를 얻었던 것이다. 둘째, 당시 르 동의 형이 르동에게 보낸 편지에서 "바스크 지역의 산과 풍 경이 르동의 취향에 맞을 것이며, 소문으로 알려져 있는 '생 생한 눈이 특징적인 아름답고 우아한 소작농 여인'에게 눈이 팔릴 것”이라고 하였다(Druick 등 1994). 이러한 여성에 묘사 는 Figure 3과 유사하며 르동의 형이 르동의 취향을 미리 알 았다고 짐작이 된다. 셋째, 르동은 후에 이 지역에 대한 경험 을 ‘바스크 지역에서의 체류’라는 소설로 적었는데, 자신을 Theophile로, 바스크 지역 여인을 Therese란 이름으로 불렀 다. 여기서 Therese를 자연적인 취향과 고귀함, 도덕성이 동 시에 있으며, 고독 속에서도 심연에 있는 존재감을 보존하는 '때 묻지 않는 꽃'으로 이상화하였다(Druick 등 1994).

이런 이상화의 흐름은 20대의 그의 회화에서 위에서 설명 한 ‘버려진 아이’의 자기 표상이 스며든다(Figure 4, 5). 위 그 림을 그린 시기는 1864년 보르도에서 르동에게 동판화를 통 해 검은 세계를 안내해준 브레댕에게 (아버지의 시선을 피

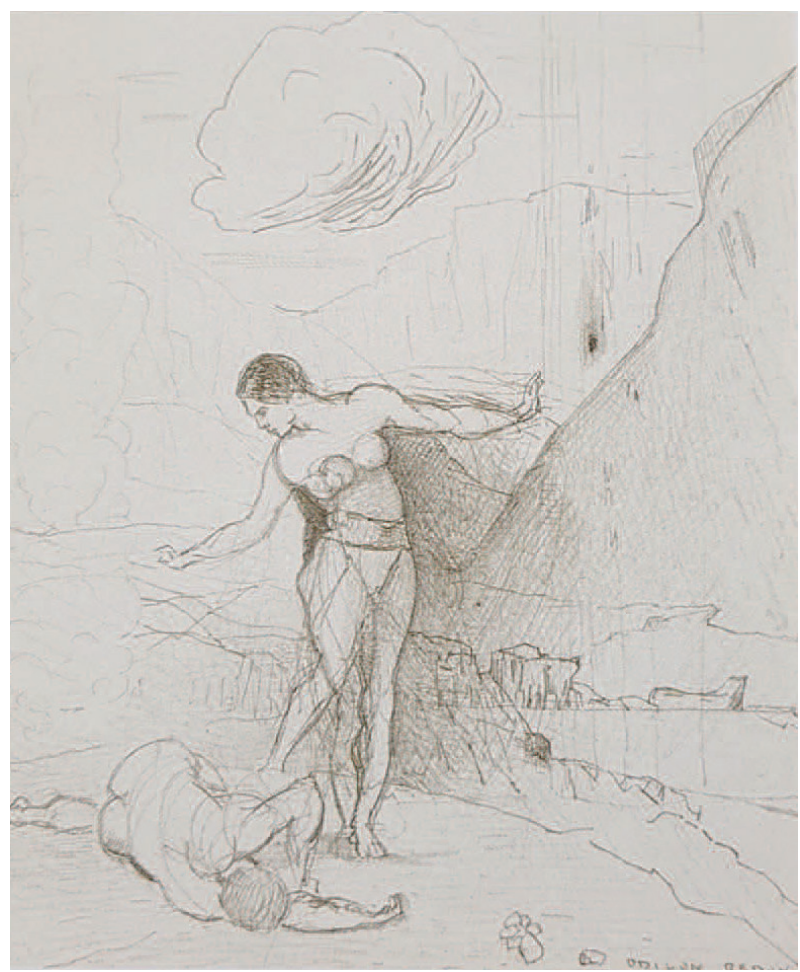

Figure 4. Eve Discovering the Body of Abel (1866), Graphite, 19.3* $16 \mathrm{~cm}$, Private collection.

해)배우는 시기였다. Figure 3의 어머니 대상은 Figure 4에 서 성경의 이야기를 변형한 자신의 이야기로 구체화된다. 제 목 '아벨의 몸을 발견한 이브’에서 암시하듯, 이브를 카인의 어머니로 설정함은 그림에서 버려진 아벨은 르동 자신이고, 차가운 듯한 반응을 보이는 이브의 모습은 그가 경험한 (자 신을 버렸던)어머니 대상인 듯하다. 특징적인 것은 이후 그 림에도 반복적으로 나오지만 여성의 가슴은 덮개로 가려져 있다는 것이다. 이는 그가 어머니의 가슴과의 거리감, 즉 접 촉이나 수유를 통한 정서(affects)가 부재함을 의미한다.

그의 자기 표상인 '버려진 아이'는 성경의 다른 이야기로 전환된다(Figure 5). 그의 어머니 대상은 아브람에게 버려진 하갈(Hagar)이고, 그녀가 안고 있는 그녀의 아들로 추정되는 이스마엘은 버려진 아이인 르동 자신으로 표현되었다. 여기 서 인상적인 부분은 Figure 4의 차가운 이브가 그의 '버려진

f창세기 4장에 따르면 카인과 아벨은 아담과 이브의 아들이었다. 카 인은 농부로 신에게 첫 제사를 올렸지만, 신은 양치기인 아벨의 제 사를 받는다. 이에 분노한 카인은 신 몰래 동생인 아벨을 살인한다. 아마 르동은 신에게 보호를 받지 못했기 때문에 아벨이 죽었고, 그 모습을 자신의 자기 표상으로 생각한 듯하다.

${ }^{8}$ 하갈은 아브람의 아내 사래의 하녀로 사래가 나이가 들도록 임신을 못하자 하갈을 아브람의 첩이 되게 하여 잉태하게 한다. 하갈이 아들 이스마엘을 얻자 오히려 그의 여주인인 사래를 멸시하고 이를 알게 된 아브람은 하갈과 그녀의 아이를 내쫓는다(성경 창세기 16 장 참조). 


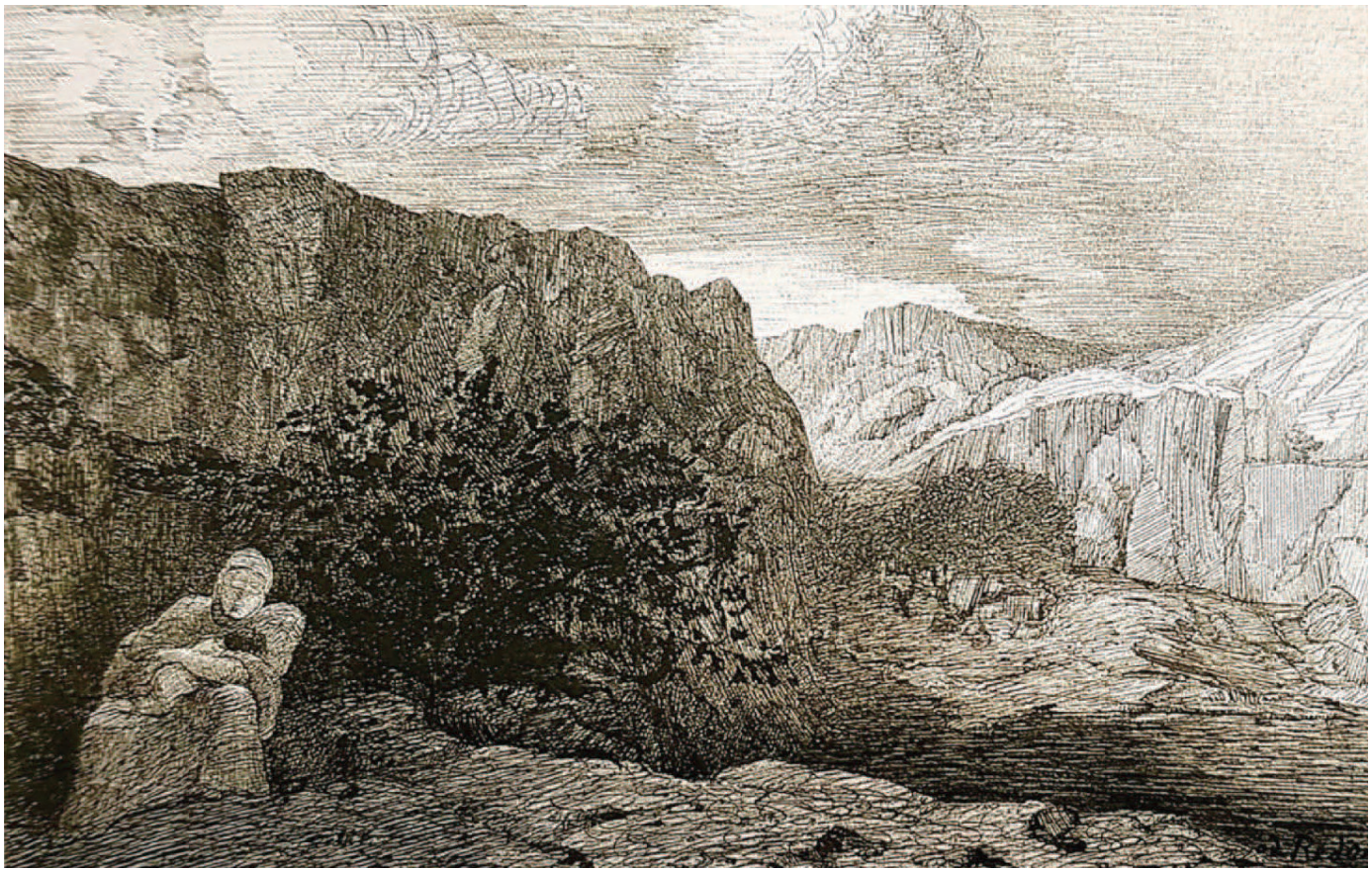

Figure 5. Hagar and Ismael (1866), Pen and ink, 10.2*15.2 cm, The British Museum.

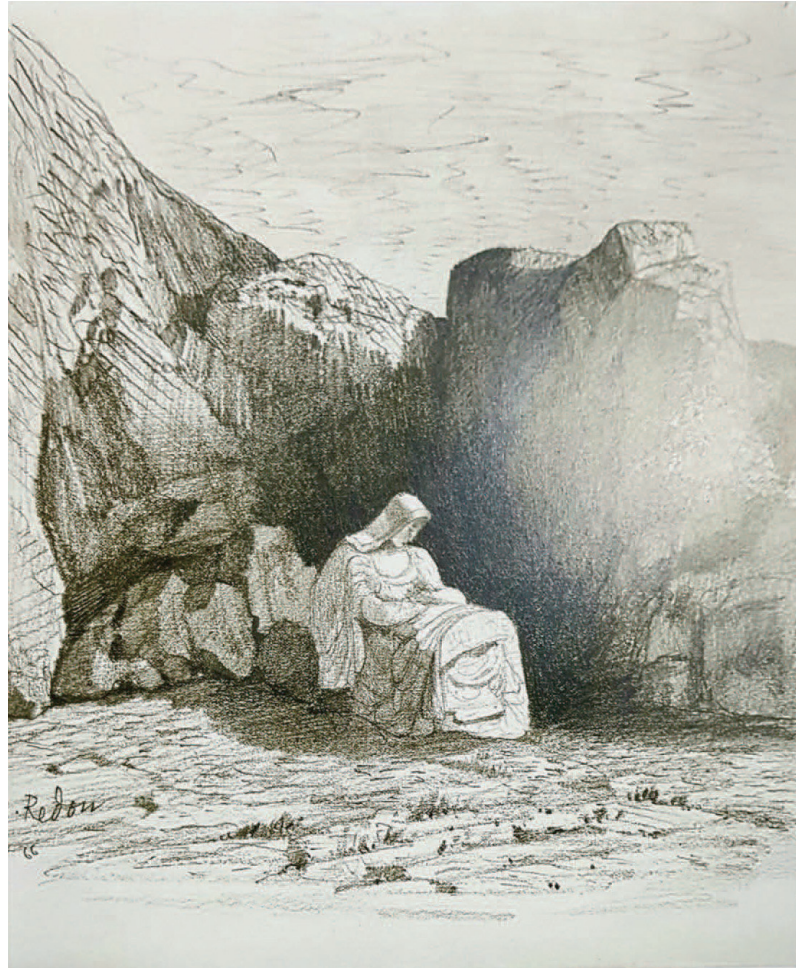

Figure 6. Hagar (1866), Graphite, $24.6 * 20.6 \mathrm{~cm}$, Private collection.

아이' 표상과 연결된 (아브람에게)버려진 하갈로 바뀌었다는 것이다. 즉 전의 차가운 어머니가 (버려진)하갈로 변화됨으로 그를 안을 수 있게 된다. 이는 그가 경험했던 어린 시절 그를 버렸던 어머니에서 서서히 그의 자기 표상과 어울리는, 따라

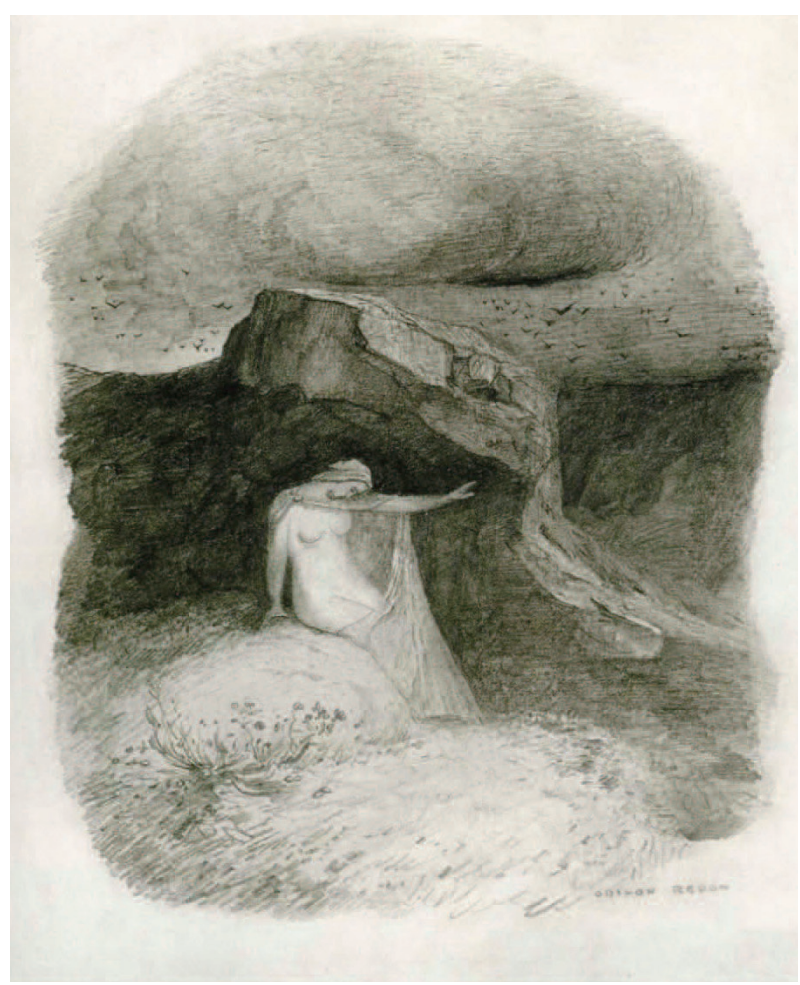

Figure 7. Seated Woman with Outstretched Arm (1868), Graphite, $28.7 * 22.3 \mathrm{~cm}$, The Woodener family collection.

서 그를 안을 수 있는 어머니로의 변화를 의미하는 듯하다.

Figure 6의 하갈은 아이를 안고 있는 듯하지만, Figure 5 처럼 아이가 보이지 않는다. 또한 비슷한 시기에 그린 Figure 7의 여인은 하갈이란 이야기를 떼어내고 아이가 없이 바 
위에 손을 뻗치고 있다.

이 일련의 회화들에 대한 무의식적 관점에서의 설명은 아 이들이 어머니와 합일되는 환상(merging fantasy) 또는 꿈의 작업에서 보이는 압축, 전치, 개별적 상징의 역동의 기전이 표현된 것이다(Freud 1900).

그럼 이 주인공 여인이 숨어있는 바위에서 벗어나면 어떻 게 될까? 이를 추측할 수 있는 그림이 Figure 8인 듯하다. 여 전히 두 손을 뻗고 있는 모습을 한 여인은 바위의 그늘에서 몇 걸음 나온 듯하다. 암울한 배경(Figure 7)은 밝은 태양으 로 인해 밝아졌다. 르동의 그림에서 낮과 태양은 군주적인 아버지를 상징한다. 무기력하게 보이는 여인의 뒤에 바위의 그림자와 은밀하게 겹쳐 누워 있는 메피스토펠레스 $\mathrm{h}-\mathrm{O}$ 표 시 부분-가 보인다(Figure 8). 태양이 보이는 배경과 대비 되어 어두운 바위산의 모양과 결합된 메피스토는 르동의 회 화에서 종종 등장하는 인물로(Figure 9), 마른 얼굴과 각이 선 코가 특징적이다. 파우스트의 소설 인물처럼 전통적인 이 성이나 종교의 틀에서 벗어나 감각, 감정, 욕망을 표상하는 세계로 유혹하는 인물을 상징한다. 아버지 대상-태양-과 어머니 대상 사이에 숨어 있는 메피스토는 이성의 그늘에 억압된 무의식을 의미한다.

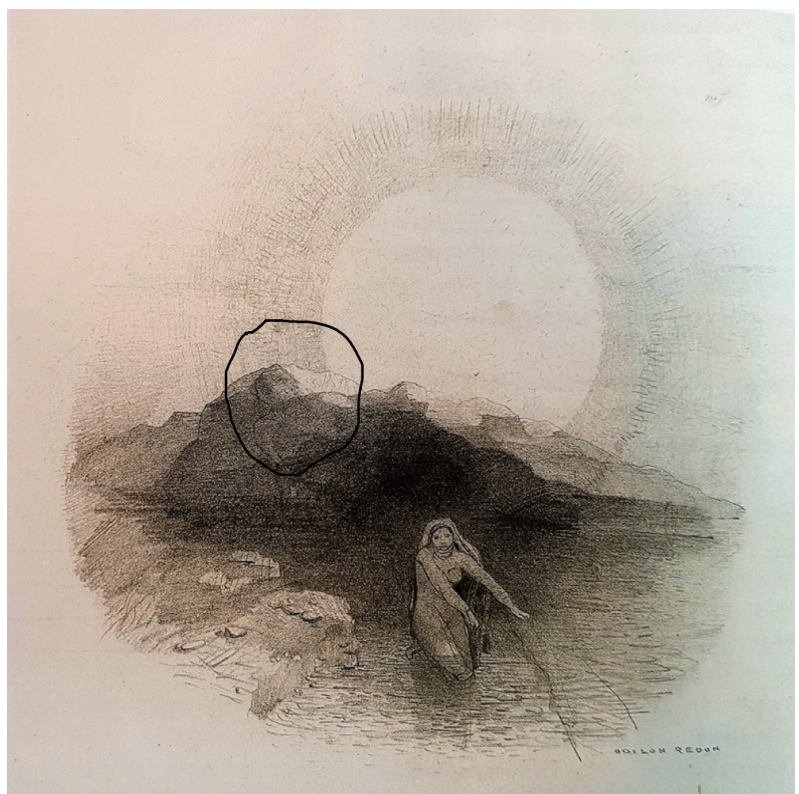

Figure 8. Kneeling Women with Outstretched Arm (1868), Graphite, $26.6 * 28.5 \mathrm{~cm}$, Private collection.

$\mathrm{h}$ 괴테의 소설 파우스트에서 나오는 악마이다. 종교와 이성의 틀에 있 는 파우스트 박사를 유혹하여 다양한 감각과 이단 등의 세계를 경험 하게 해준다. 메피스토라고 불린다.

i성가족은 성경에서 아기 예수와 마리아, 그의 혈육의 아버지인 요셉 을 함께 그린 주제이다. 중세시대부터 르네상스 등 서양 미술사에서 계속 다양한 방식으로 다루어진 주제이다.
이러한 흐름에서 1970년 그려진 르동의 성 가족(Holy Family)은 아직 불안하다(Figure 10). 메피스토의 얼굴을 한 아버지 요셉은 마리아와 아이를 보고 있다. 뒤에 태양의 강

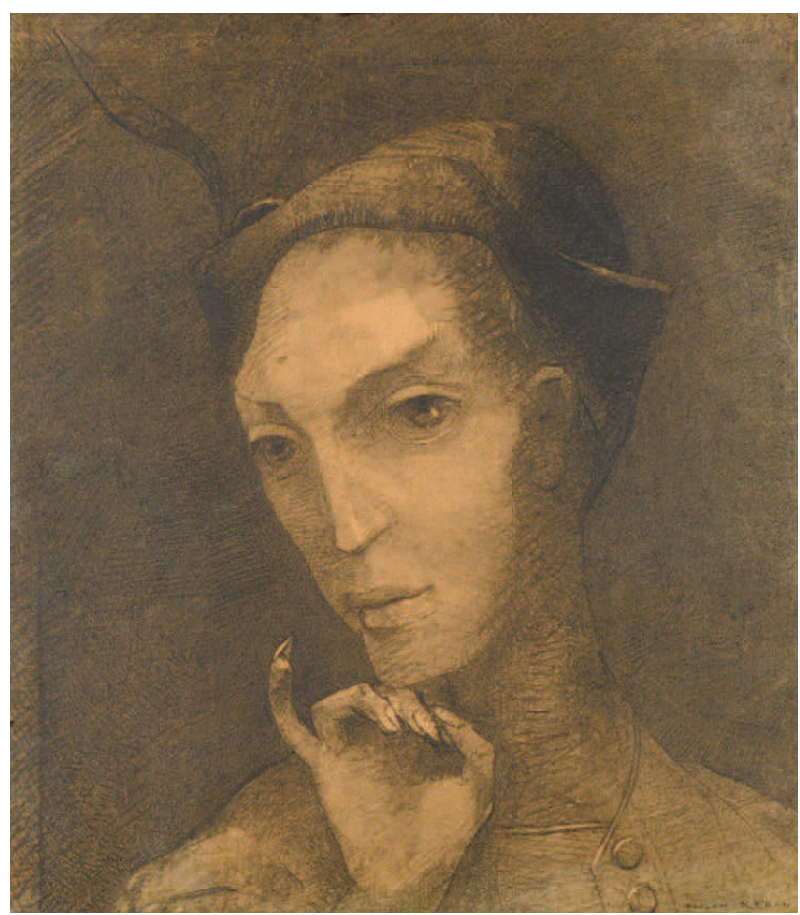

Figure 9. Mephistopheles (1877), Charcoal, $34.3 * 39.4 \mathrm{~cm}$, The Morgan Library \& Museum.

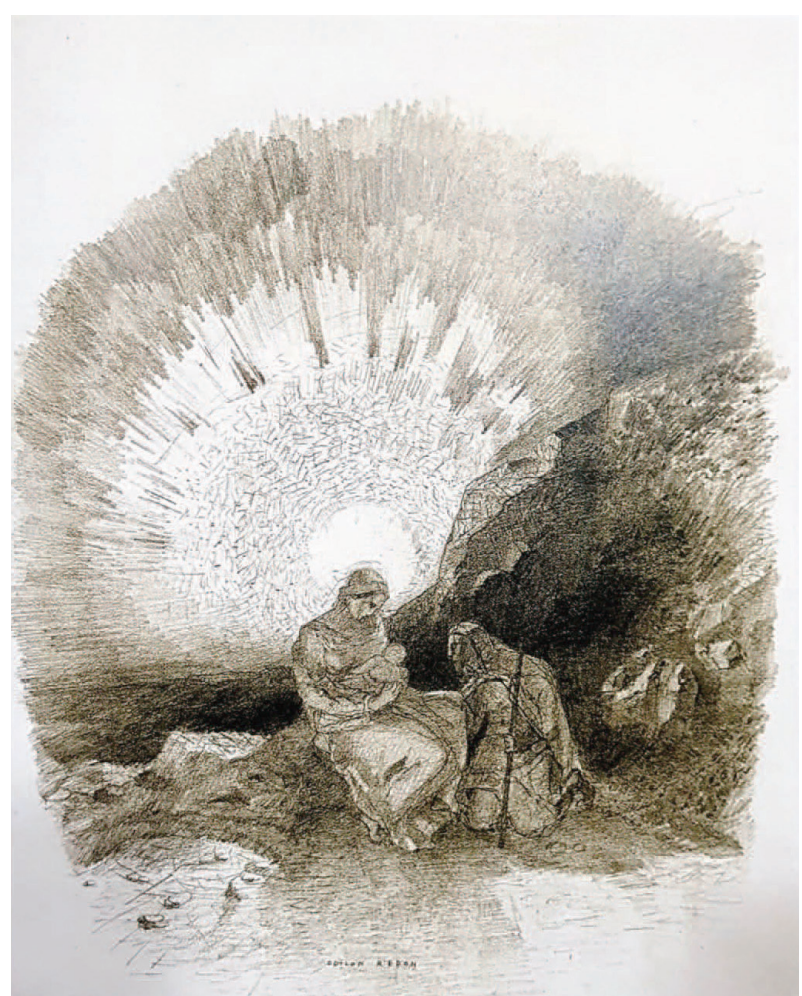

Figure 10. Holy Family (1870), Graphite, $30.6 * 23.5 \mathrm{~cm}$, Private collection. 
한 빛이 인상적이다. 아버지 빛에 의해 만들어진 부분 대상 인 메피스토는 부인과 아들을 보호하는 듯하지만 동시에 위 협하거나 유혹하고 있는 듯하다. 다른 인물과 다르게 태양의 빛을 피한 바위 아래 있는 것이 위 이미지(Figure 8)와 같은 흐름이다. 파우스트의 책처럼 기존 이성과 종교의 체계에서 악마화되었지만, 그 구조 밖의 감각과 감정, 사고 등을 품은 메피스토는 새로운 시대에서는 대안의 역할-마치 무의식처 럼을 하는 것이다.

이 시기 이후 르동 내면의 여성성은 고통스럽지만 구체성 을 띤다. 사실 예술가의 숙명은 그리스 신화의 미르쉬아스 처럼 그 사회가 허락하지 않는 감각과 감정, 사고 체계를 느 끼는 사람이며 이를 표현하는 고통을 감내해야 된다는 인식 이 있었다. 특히 당시 사회에서는 이성에 반대하는 낭만주의 운동으로 인해 감정이나 감각, 이를 통한 내면의 인식과 표 현에 깊은 관심을 가지고 있었고, '어머니'는 그 감각이나 감 정 등을 보유한 존재로 여겨졌다. 따라서 위 회화의 흐름에서 르동의 내재화된 여성성은 사회 구조의 억압-저자는 이를 초자아 구조라고 말한다-으로 인해 여전히 고통스럽다(Figure 11). 르동의 심리에 큰 심리적 전환점인 군 입대(1870년) 와 아버지의 죽음(1874년) 이후, 참전에 의한 자신감과 아버 지 죽음으로 인한 해방감이 있더라도 이 그림은 그렇지 않 다. 고뇌하는 천사의 표정과 자세, 오른 손목에 수갑, 공포를 상징하는 붉은 하늘 등의 장치로 날개가 있지만 날아가지 못하는 르동의 내재화된 여성성은 그의 무의식의 복잡한 갈 등을 나타내는 듯하다. 처벌적인 아버지 대상과의 관련성이

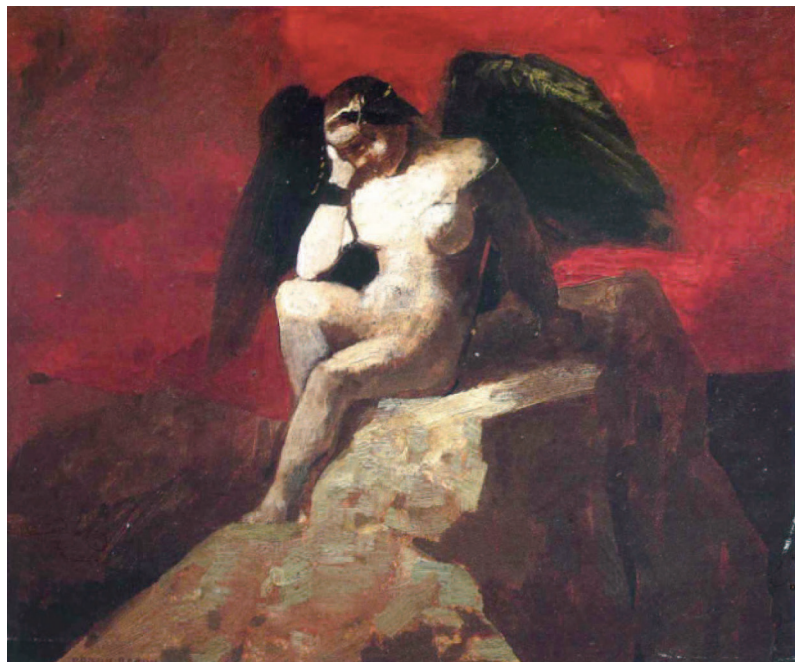

Figure 11. Angel in Chain (1875), Oil on paper laid down on board, $22.4 * 27 \mathrm{~cm}$, The Woodner family collection.

jo아폴론과 수금 대결을 하다가 결국 나무에 피부를 벗기는 형벌을 받 으며 죽었다. 이 신화는 이성과 제도화된 예술을 상징하는 아폴론을 대적하면 안 된다는 이야기를 의미한다.
깊은 이 그림(Figure 11)은 뒤에 다시 거론될 것이다.

1876년 그려진 Figure 12은 일련의 회화의 흐름을 통해 본다면, 태양 아래에서 아이와 메피스토를 동시에 품은 듯하 다. 여전히 위 천사(Figure 11)처럼 어두운 표정이지만, 그의 이상화된 여성성은 '아버지 대상에 의해 악마화 된 감각, 감 정, 사고'-메피스토-와 르동의 깊은 상처인 '버려진 아이' 를 동시에 품었다. 또한 Melancholy란 제목처럼 무거움이 가득하지만, 그는 태양을 피하여 바위 아래 숨지 않았다. 이 는 비록 불안정하지만 시대의 틀에서 벗어난 '여성성'이 초자 아 처벌의 공간에서의 고통을 감내하며 드러낸 것이다. 이는 정신분석학적 관점으로는 억압된 무의식의 세계를 느끼는 용기를 드러낸 것으로 이해되며, 그 힘의 지지는 아마도 위에 서 말했듯 그의 참전 경험과 아버지의 죽음, 그리고 그의 예 술의 영원한 지지자 겸 동반자인 부인이 될 카미유를 만났기 때문일 것이다. 이러한 현실과 심리적인 변화 시기에서 1877 년 극적인 그림을 그린다. 그의 악마와 천사가 화해를 하는 것이다(Figure 13). 어두운 솦 속에서 천사 good object-와 악마- bad object-가 손을 잡고 걸어간다. 검은 공간에서 이 루어지는 이 장면은 당시 르동의 심리를 표현함과 동시에 이 시기 다른 이미지들과 함께 평행하면서 이후 본격적인 검은 시대에 반복되는 선과 악, 그리고 화해의 순환에 중요한 길 을 제공한다. 하지만 화해한 악마는 분리되어 있고 악마 자 체는 어두운 배경과 겹쳐 그려져 구체화되지 않았다. 아직 가야 할 길이 많은 것이다.

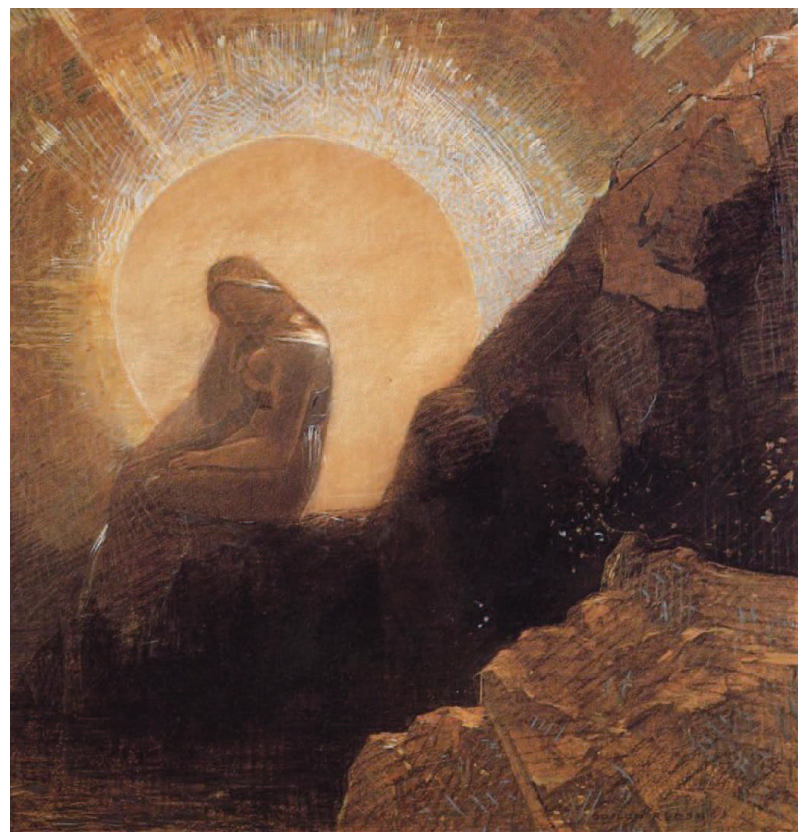

Figure 12. Melancholy (1876), Charcoal, gouache, pastel, and black chalk, $36.8 * 35.7 \mathrm{~cm}$, The Art Institute of Chicago. 


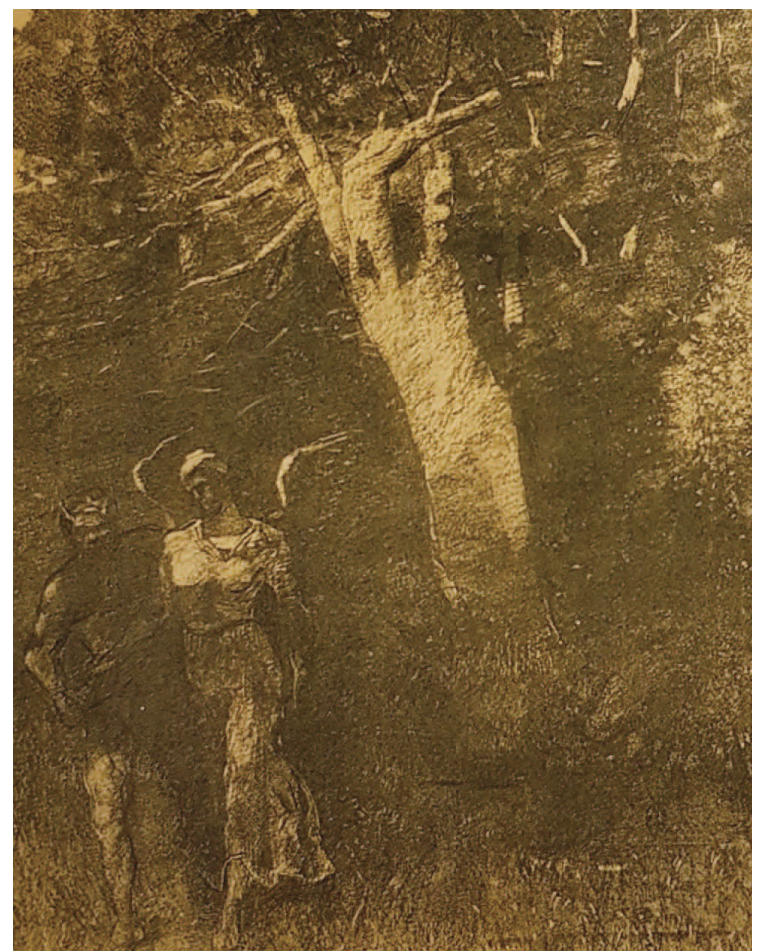

Figure 13. Angel and Demon (1877), Charcoal, $46 * 36.3 \mathrm{~cm}$, Musee des Beaux-Arts.

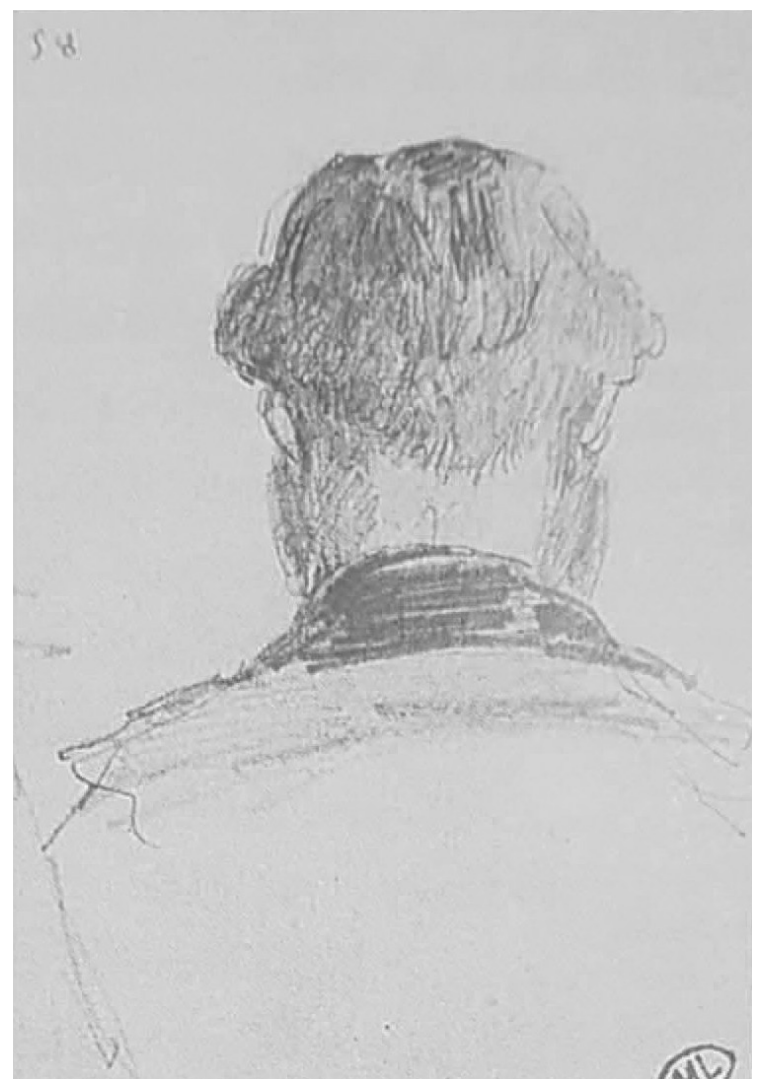

Figure 14. Bertrant Redon (1858), Graphite, $8.2 * 5.7 \mathrm{~cm}$, Musee du Louvre.

\section{아버지 대상}

Figure 14는 르동이 유일하게 그린 아버지 초상화이다. 실 제 어머니를 그리지 않은 것을 통해 르동의 어머니에 대한 태도를 짐작할 수 있는 것처럼, 이 뒷모습의 그림은 아버지 에 대한 르동의 의식적인 태도와 무의식적인 역동을 드러내 는 듯하다. 하지만 그가 40대 후반에 실제로 아버지에 대한 언급한 내용은 양가적인 부분이 보인다(Redon 1986).

\section{〈인용문 3〉}

$\cdots$ 나의 아버지는 (어린)나에게 종종 말하곤 했다. "이 구름들을 보아라. 내가 보듯, 구름 사이에서 변화하는 모양들이 보이지 않 느냐?" 그리고 나서 이 변화하는 하늘에서 그는 환상적이고 경이 로운 광경을 보여주었다. 그는 자연을 사랑하였고 종종 나에게 아메리카 초원에서 느낀, 그가 정복한 광대한 숲에 대하여 말하 였다 $\cdots$ 식민지 개척자였으며 흑인을 거느렸던 그는 가족들에게 자신의 모험을 이야기했는데, 그는 독립적이고 거칠었으며 고압 적인 존재라 나는 그 앞에서 늘 심한 불안감을 느꼈다 $\cdots$

여기서 어린 르동은 아버지에 대하여 심한 불안감과 공포 를 느낀 듯하지만, 동시에 르동의 예술적인 감성을 이해하고 자연을 소개시켜주는 이상화된 대상으로 여긴다. 이렇게 분 리된 아버지 대상에 대한 태도는 그의 전 생애를 통해 분열 된 형태로 실제 대인 관계 및 회화에서 반복적으로 나타나게 된다. 그를 이해하고 상상력을 자극하는 이상화된 대상에 대 한 관계는 앞서 설명한 것처럼, 고랭이나 아르망 클라보, 브 레댕 등 실제 인물과의 관계에서 반복적으로 잘 드러나며, ${ }^{k}$

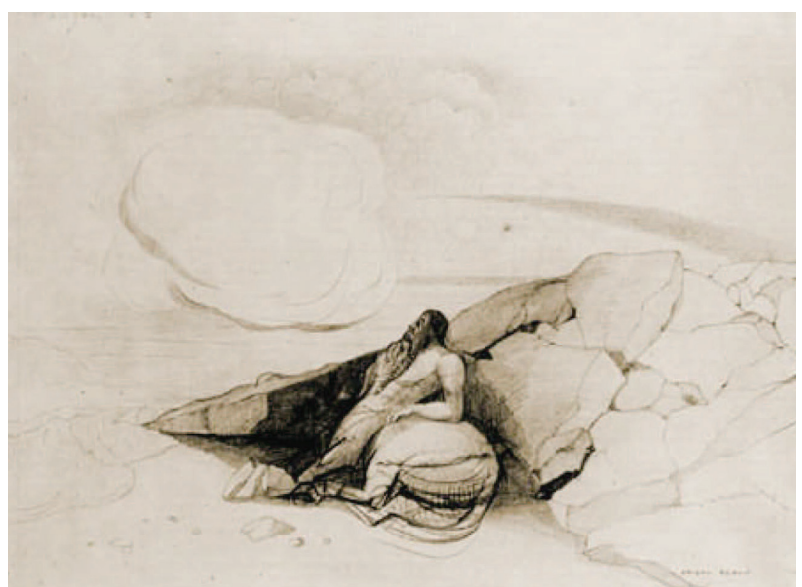

Figure 15. Centaur Contemplating a Cloud (1863), Graphite, 21.3* $32.1 \mathrm{~cm}$, Oeffentliche Kunstsammiung Basel.

${ }^{k}$ 르동의 10 대나 20 대에는 그의 일상에서 그의 형에게 실제적인 의존 을 깊게 한다. 그의 형은 당시 보르도에서 음악 및 지방 언론에서 유 명하고 유력한 인물이어서 르동은 실제 삶에서 그의 형의 그늘에 있 게 된다(Druick 등 1994). 


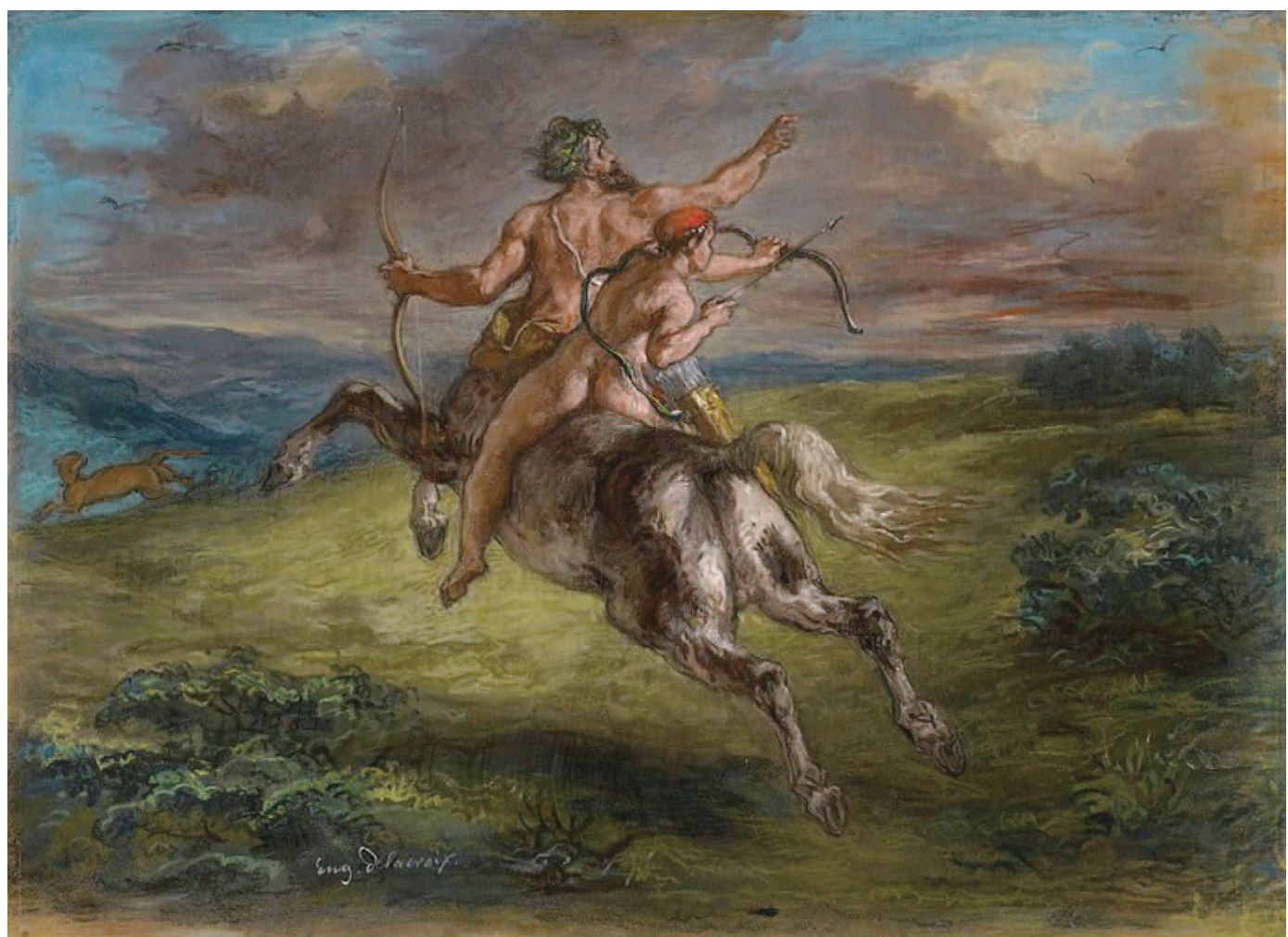

Figure 16. Eugene Delacroix (1798-1863), The Education of Achilles (1862), Oil on canvas, Private collection.

처벌적인 모습으로서 아버지 대상은 제롬과의 관계에서 잘 나타난다. 또한 르동에게 아버지는 의존적 대상으로서 역시 중요하다. 그의 작품이 본격적으로 팔리기 시작한 50대가 되 기 전까지 경제적으로 아버지의 재산에 그의 생활을 전적으 로 의지했었다. 또한 위 르동의 간략한 삶에서 기술한 것처 럼 20대에 건축을 전공을 선택한 것은 오로지 그의 아버지 의 의견에 따르고자 함이었다. 그는 1874년 아버지가 사망 한 이후라도 실제적으로나 심리적으로 정도의 차이는 있었 지만 아버지 그늘 아래에 있었다(Druick 등 1994).

몇 가지 살펴본 미술사적인 증거들처럼, 무의식적 관점에 서 르동의 그의 분리된 아버지는 다양하게 변형된 모습으로 그의 회화에서 표현된다. Figure 15는 르동의 정신적인 멘토 인 들라크루아가 1863년 8월 죽은 후에 그린 그림이다. 낭만 주의 시대를 연 들라크루아는 르동이 지향하는 내면을 향한 회화를 구현한 선구자였다. 사람의 몸과 말의 몸을 가진 켄 타로우스(Centaur)'가 바위에 누워 '구름'을 명상에 잠긴 듯 바라보고 있다. 여기 구름은 〈인용문 3〉에서 볼 수 있듯 예술 적인 아버지 대상을 연상시킨다. 켄타로우스 표정이 외롭고

그리스 신화에 등장하는 반인반마 종족이다. 상체는 인간이고 가슴 아래부터 뒷부분은 말이다.켄타로우스종족은 방탕하며 폭력적인 인 간의 모습을 상징하지만 한편으로는 켄타로우스족의 현자 케이론은 영웅들의 스승으로도 유명하다.
지친 듯하다. 말의 몸은 뒤에 반복적으로 표현될 르동의 본 능의 표상이며, 현자의 모습을 한 켄타로우스 족의 현인 카 이론(Khiron)은 그 동물성을 길들이는 스승으로서 들라크루 아를 상징한다(Druick 등 1994). 이러한 것을 설명하는 그림 은 들라크루아의 Figure 16이다. 그리스 신화의 영웅인 아킬 레우스에게 활을 친절하게 가르치는 카이론과 이것을 그린 들라크루아는 르동이 바라는 이상화된 아버지를 의미한다. 이후 르동의 회화에서 말과 관련된 주제는 그의 평생 다양 한 형태로 표현된다.

1864년 제롬의 교육을 받는 시기에 아버지와의 관계를 상 징하는 '구름'은 다른 형태를 띠게 된다(Figure 17). 앞서 그 가 버림받은 아이를 그렸던 Figure 2의 시기로, 그림을 지도 하는 그의 아버지 대상인 제롬은 그에게 상상력을 격려하는 것이 아니라 그를 억압하였다. 따라서 '구름'은 르동을 위협 하고, 카이론을 상징하는 말과 보호자는 아이-르동 를 안 고 피하게 된다. 비슷한 시기 1865/6년 그는 다소 난해한 그 림으로 자신의 내면 세계를 표현한다(Figure 18). 헬멧을 쓴 한 갈리아 $(\mathrm{Gaul})^{\mathrm{m}}$ 장수가 오크 나무 아래 앉아있는데 이 장 수는 다름 아닌 켄타로우스이다(Druick 등 1994). 갈리아인

${ }^{\mathrm{m}}$ 고대 로마인이 부르던 켈트족을 일컫는다. $\mathrm{BC}$ 6세기 경에 북이탈리 아, 프랑스, 벨기에 일대에 거주하던 민족으로 BC58 51년 로마 황 제 카이사르에 의해 갈리아 전쟁으로 평정되었다. 


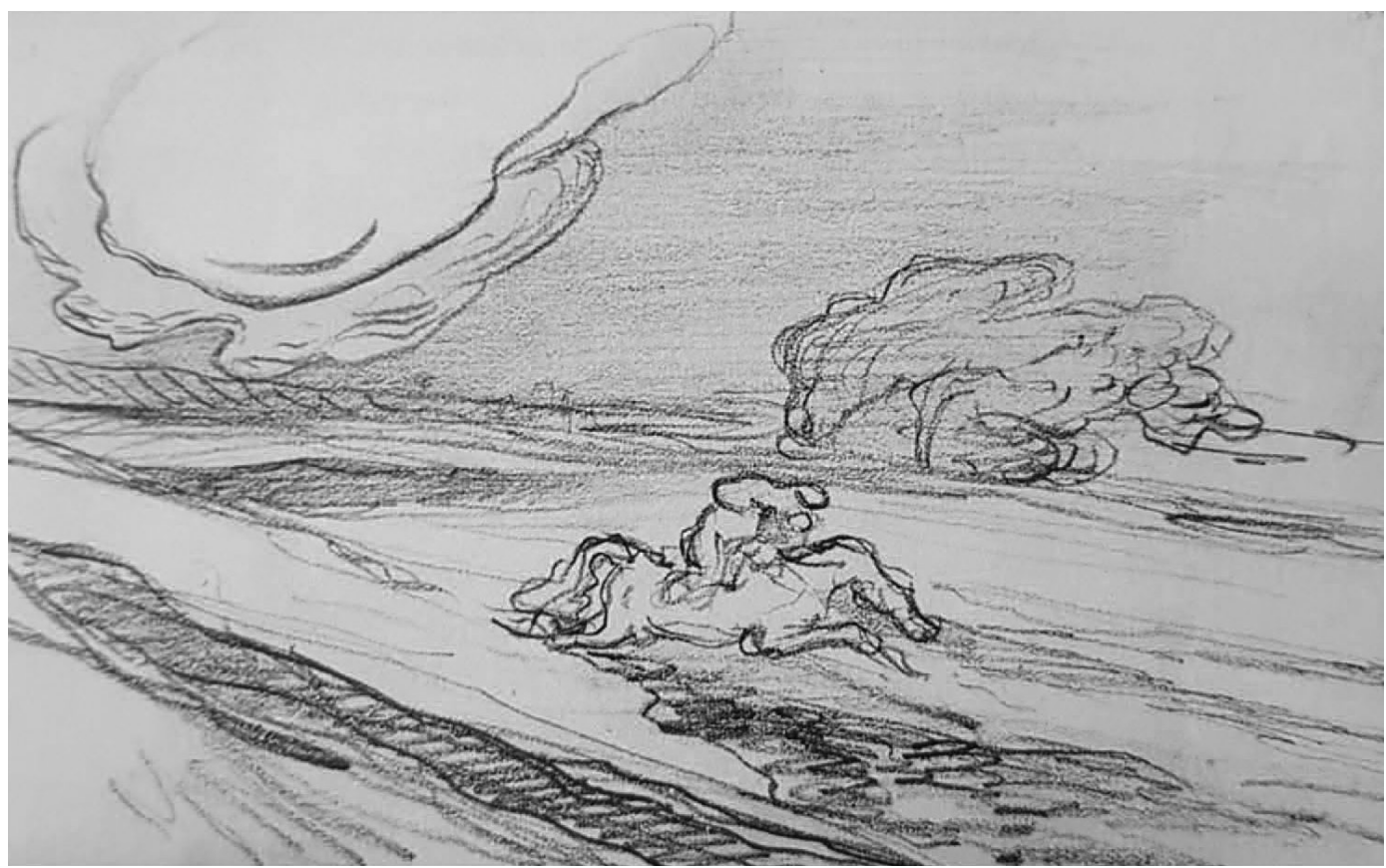

Figure 17. Landscape with Two Figures on Horseback. From sketchbook 1., folio 39 (1864), Graphite, 10*16.2 cm, Musee du Louvre.

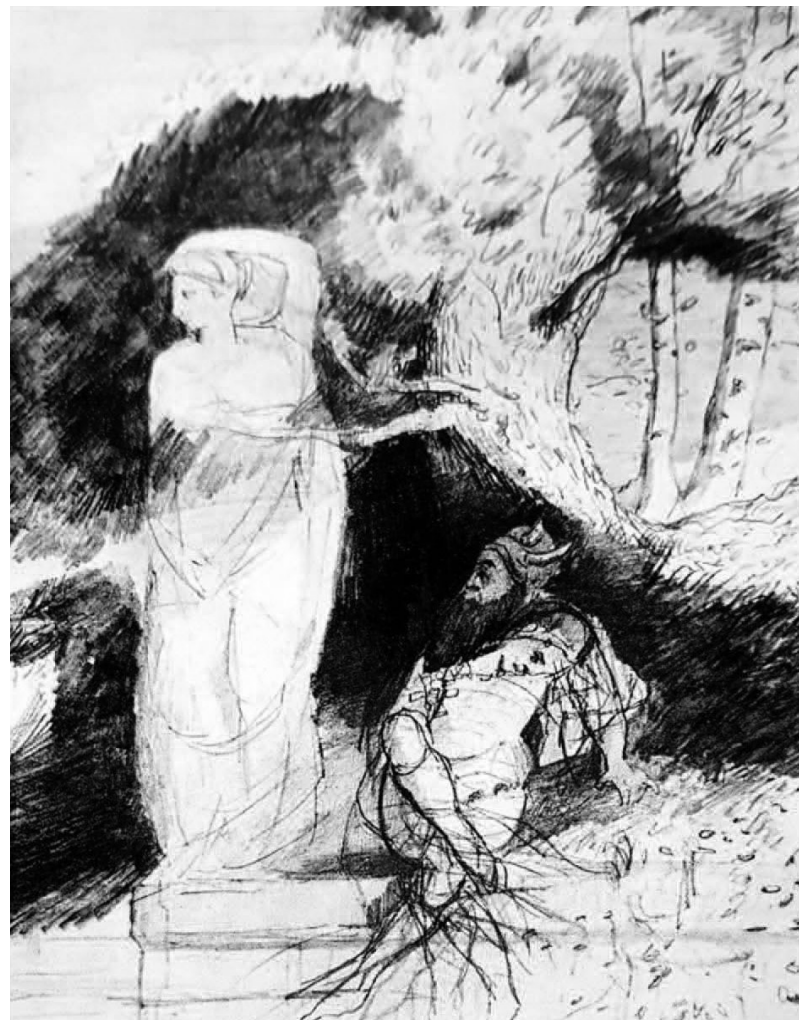

Figure 18. Seated Gaul and Classical Statue in Wooded Landscape (1865/6), Graphite, $30.4 * 22.9 \mathrm{~cm}$, Location unknown.

은 독재자인 케이사르에 저항한 민족으로 그 당시 프랑스 민 족주의에 영향을 주었던 민족이었다. 여기에 르동은 자신의 개인적인 의미를 부여하였다. 제롬과 평행하는 독재자 케이사

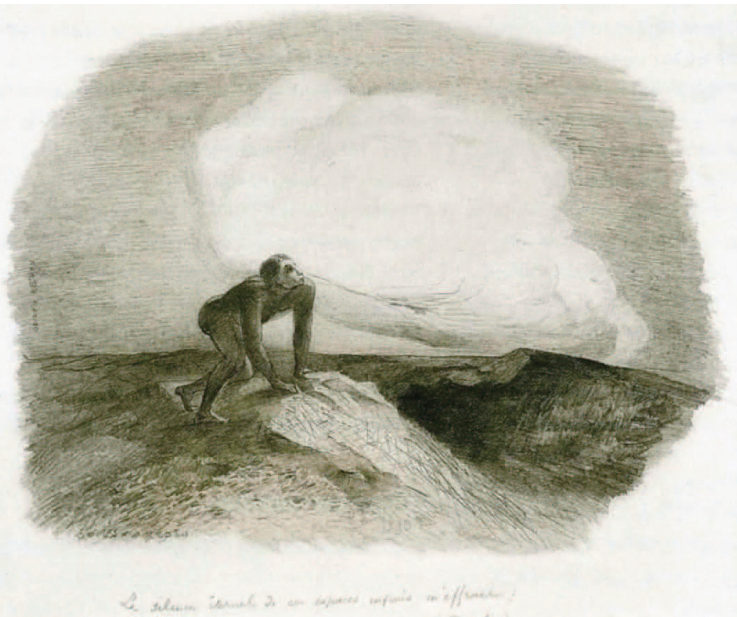

Figure 19. The Eternal Silence of These Infinite Space (1870), Graphite, $22.5 * 27.5 \mathrm{~cm}$, Musee du Petit Palias.

르에게 상처받은 갈리아 장군에 자신의 모습을 투사하여 그 린 듯하다. 당시 오크 나무가 켈트족의 종교인 드루이드(Druid) 종교의 비유적 의미이므로, 장수 옆에 있는 오크 나무 숲의 여신상은 독재자적인 아버지 대상-제롬, 케이사르-으로부터 피하고 싶은 르동의 안식처인 '이상화된' 어머니인 듯하다.

앞서 설명했듯 1870 년 참전은 르동의 심리에 영향을 주게 되고, 이와 더불어 아버지 대상 관련 회화에 변화를 가져온 다(Figure 19). 원시인이 땅을 짚고 구름 아버지 대상-근 처에 와있다. 이 '원시인'은 동물과 인간 형상의 복합체인 켄 타로우스가 압축되어 진화된 모습으로 짐작되며, 분리된 모 습이 아닌 벌거벗은 모습으로 하늘을 지배하는 초자아 대상 


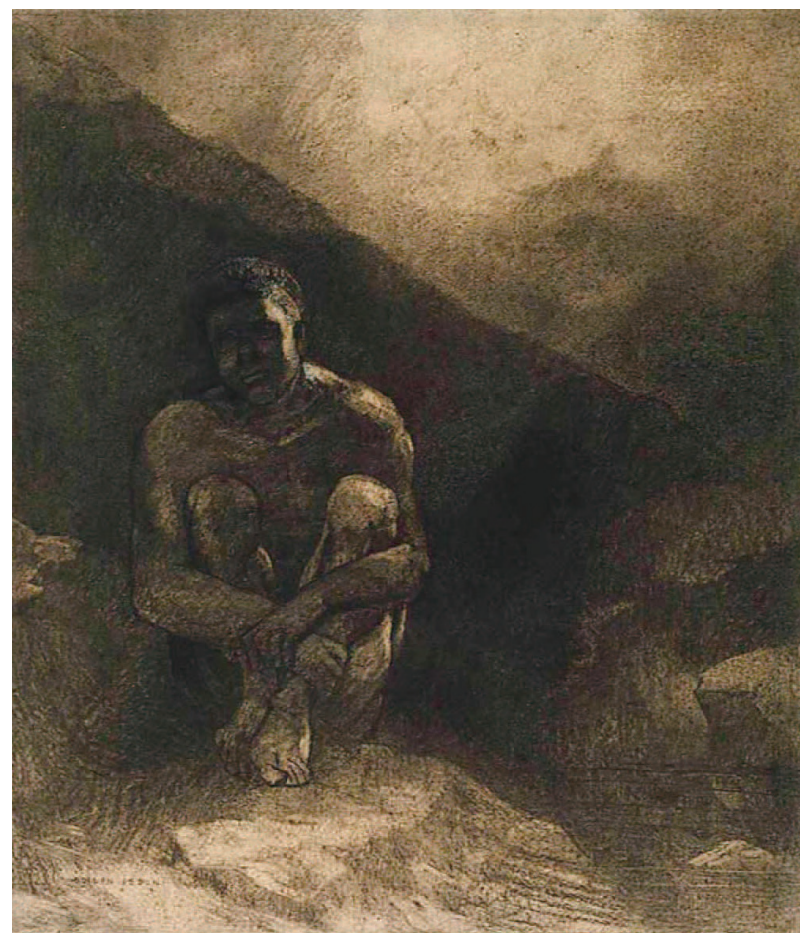

Figure 20. Primitive Man (Seated Shadow) (1972), Charcoal, 39.3* $33.8 \mathrm{~cm}$, The Art Institute of Chicago.

에 접근을 한 것이다. 하지만 실제 사건으로부터 얻은 정신 적인 고양감과 자존감의 상승으로는 그의 무의식에 일시적 인 변화를 준 듯하다. 이후 회화의 흐름은 다시 어두운 그늘 과 같은 곳에서 초자아의 시선을 피해 숨게 된다(Figure 20). 특히 Figure 21에서 큰 날개가 있지만 날지 못하고 떨어져 바위 아래 있으며, 그의 시선은 하늘을 향해 있어 Figure 19 와 명확한 비교가 된다.

이러한 르동의 마음은 1874 년 실제 아버지의 죽음과 그의 미래의 아내를 만남으로 회화에서 극적인 변화가 보인다. 대 표적인 회화는 1875년 작(Figure 22)이다. 초자아 공간인 하 늘에 자신이 동일시했던 켄타로우스가 화살을 쏜다. 르동은 당시 이러한 종류의 그림을 반복적으로 그렸다고 하며 (Druick 등 1994), 이는 분명 억압되었던 아버지 대상을 향 한 해방감과 동시에 쌓였던 (본능적인)공격성이 이미지로 표현되었을 것이다. 하지만 정신분석의 임상에서 그렇듯 실 제 아버지의 죽음이 내재화된 초자아를 없앨 수 있는 것이 아니다. 비슷한 시기 그려진 Figure 11과 23은 이에 대한 또 다른 르동의 내면을 표현된 듯하다. 두 그림의 천사는 이전 천사와는 다르게 그늘에서 나왔다. 하지만 앞서 언급했던 여 성의 몸으로 동일시한 Figure 11의 천사는 여전히 강력한 붉 은 하늘로 표현된 군주적인 초자아의 힘에 묶여 있고, Figure 23의 남자 천사는 직접적으로 아버지 초자아 대상을 상 징하는 구름을 피하고 있다. 또한 이 두 그림은 모두 이전 그

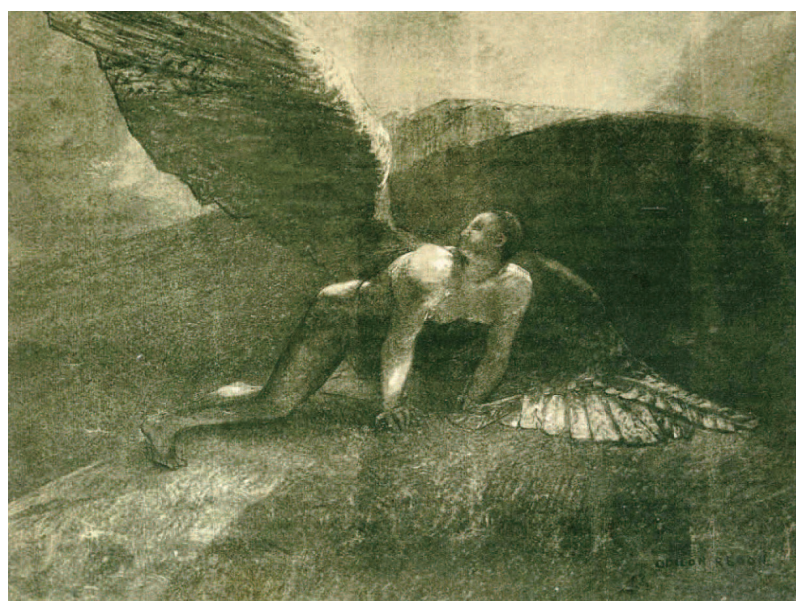

Figiure 21. The Fall (1872), Charcoal, Location unknown.

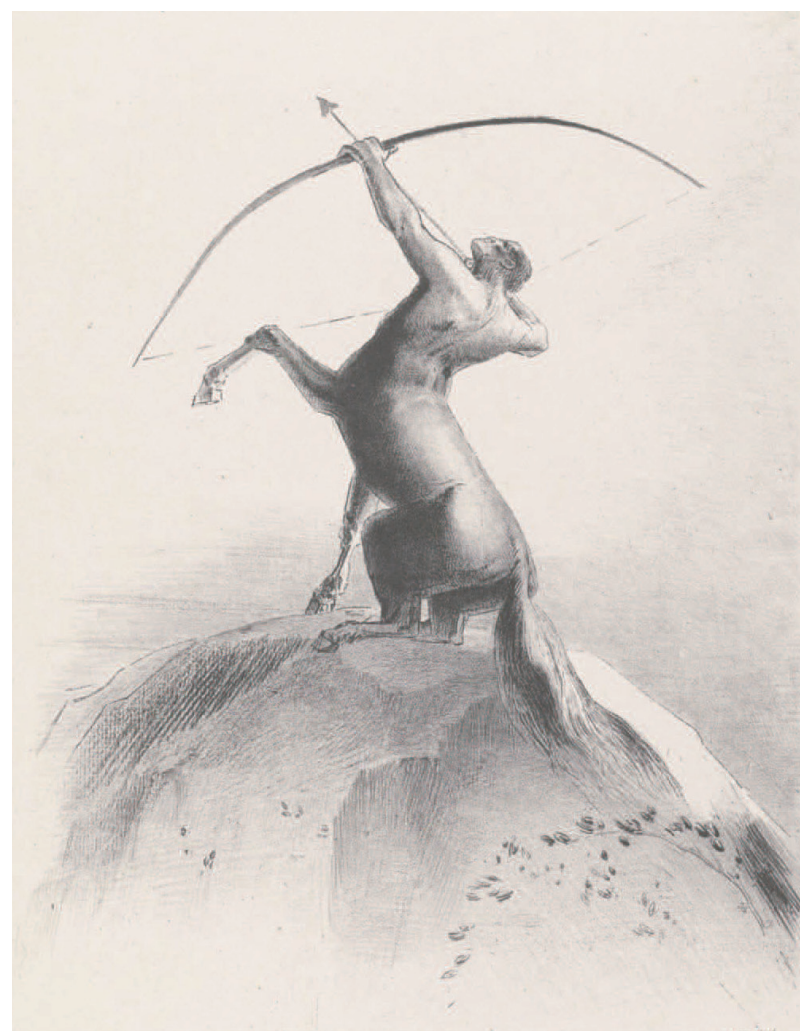

Figure 22. Centaur Taking Aim at Clouds (1875), Graphite, 26.5* $22.5 \mathrm{~cm}$, The Woodener family collection.

림과는 다르게 컬러로 표현했는데, 이는 아마도 검은색의 형 성 시기 전에 색채의 표현이 자신의 내면을 더 정확히 표현 될 거란 확신으로 짐작이 된다.

르동이 형성된 공간: 페일레버드

〈인용문 4〉

$\cdots$ 내가 무엇을 느끼는지 알기 위해서 사람들은 그곳(페일레버 


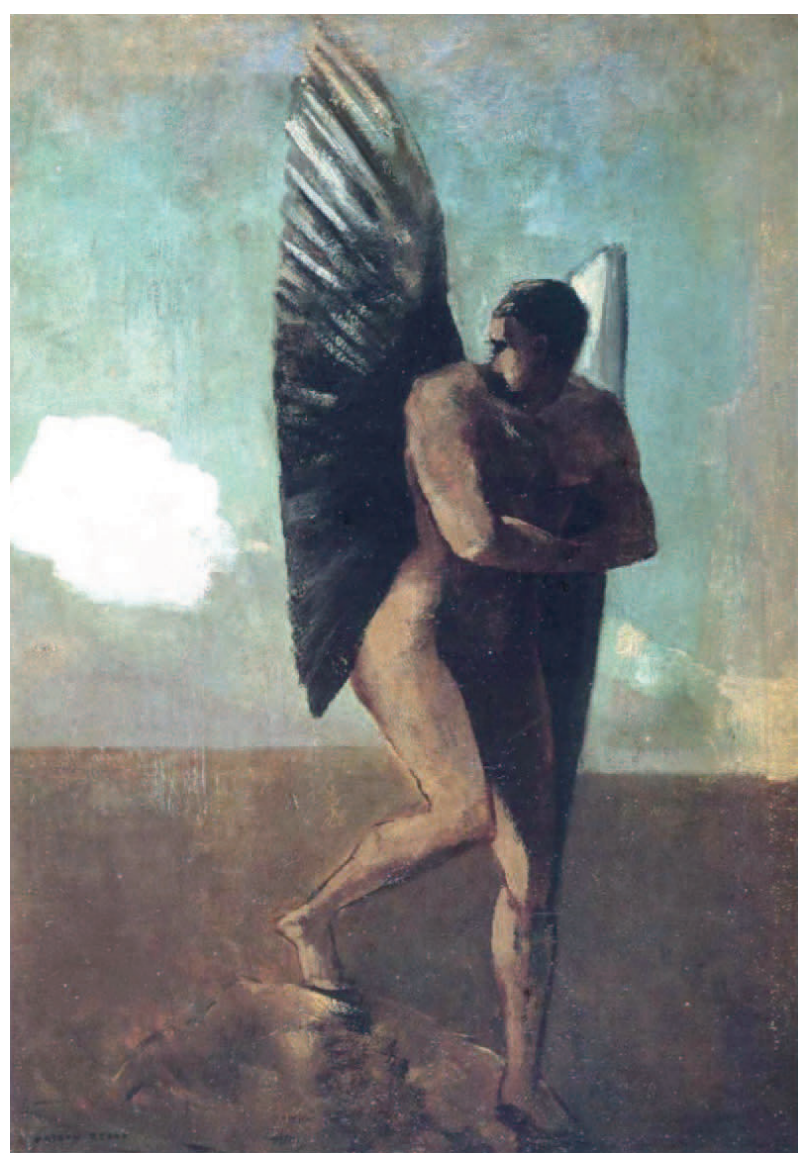

Figure 23. Fallen Angel Looking at a Cloud (1875), Oil on paper, $35 * 24.5 \mathrm{~cm}$, Stedelijk Museum.

드)에 있는 그녀, 영원한 어머니(infinite mother)를 반드시 알아야 한다 $\cdots$ (내가 그곳을 떠나려고 할 때)이 버림받는 느낌은 무엇인 가? 그것은 죽음과 같다 $\cdots$ (Druick 등 1994)

〈르동이 Emile Schuffenecker에게 1892년에 보낸 편지〉

르동은 페일레버드가 형과 어머니에 의해 팔렸던 1897년 까지 정기적으로 방문을 했다. 그는 50대가 넘었지만 여전히 그곳을 떠날 때 <인용문 4>에서 보듯 마치 아이가 어머니를 떠날 때와 같은 분리 불안을 느꼈다. 르동은 무의식적으로 페 일레버드 공간을 어머니 대상처럼 여기는 것 같다. 아래<인 용문 5>는 르동이 29세에 쓴 자서전적인 글 '그가 꾸는 꿈(Il reve')으로 어린 시절의 기억을 통해 위 내용을 역시 확인한다 (Druick 등 1994).

\section{〈인용문 5〉}

$\cdots$ 나는 나 혼자였다 $\cdots$ 나는 자연에 의해 나의 삶이 유지가 되 었다. 내가 나의 어머니의 벽으로부터 밤의 숨소리를 들었을 때, 나는 나 자신을 슬프고 부드러운 소리에 두는 것을 좋아했다. 이
러한 긴 울음 소리, 웅장한 노래 소리는 나의 영혼을 울렸고 마술 같은 세계로 인도하였다 $\cdots$ 내가 버려진 슬픈 상태에서 이러한 호 흡과 숨소리는 나의 날들과 시간들을 맴돌았다 $\cdots$ 문 밖에 나가도 같은 즐거움이 있었다 $\cdots$

〈인용문 4〉와 〈인용문 5〉에서 보듯, 11 년 동안 가족에게 버려졌다고 기억되던 공간, 고통스럽고 잔인했던 곳으로 기 억했던 페일레버드에서 르동은 마치 아이가 어머니 대상과 경험해야 할 감각과 감정을 교류(communication)했고, 이와 관련한 많은 환상들을 꿈꾸었던 것으로 짐작할 수 있다. 즉 이 공간은 어머니 대상의 대리자였던 것이다.

하지만 이 공간은 어머니 대상만 존재하는 것이 아니었다. 사실 이 장소와 집을 매입했던 사람은 아버지였고, 당연히 아버지는 이 곳의 주인이었다. 즉 어머니와 같은 자연과 깊 은 교류와 환상을 꿈꾸었어도, 그 뒤에는 늘 아버지의 지배 가 존재했던 것이다. 실제로 그의 아버지가 죽은 1874 년에 그는 그의 지인인 Ernestine Cavaroc에게 말한 아래 내용은 이를 확인한다.

\section{〈인용문 6〉}

$\cdots$ 이 오래된 땅 페일레버드는 나의 아버지의 기억이 가득 찬 곳입니다. 나는 변하지 않았던 나의 몽상들이 나오는 그곳에서 몇 달 동안 많은 시간을 보냈습니다. 나는 아버지가 개척했던 오 래된 땅과 저 벽들을 존경합니다 $\cdots$ (Druick 등 1994)

〈Ernestine Cavaroc에게 1874/5년에 보낸 편지〉

무의식적인 관점에서 르동에게 페일레버드는 그의 어린 시절 어머니와 아버지 대상과의 실제 및 상상 속의 경험이 공존하는 공간이었다. 그리고 '버려진 아이'였던 르동에게 그 공간은 환상으로 채워져 실제 대상을 상당 부분 대체한 듯하다. 즉 르동에게 대상은 공간이었던 것이며, 이는 페일 레버드 공간에서의 경험과 환상이 '나'의 형성에 의미 있는 시간이었음을 뜻한다. 이러한 르동과 페일레버드 공간과의 관계는 르동의 자기 표상의 형성에 밀접한 관계가 있으며, 이 공간에서의 다양한 환상은 르동의 자기(self) 형성에 중요 한 역할을 할 거라는 짐작을 하게 된다.

페일레버드 공간과 '나'와의 무의식적 관계는 그 공간에 대한 르동의 몇 가지 언급에서도 추가적으로 확인할 수 있 다. 르동이 페일레버드에 매년 가는 이유에 대하여 "나의 뿌 리로부터 나를 보기 위해서”라고 하였다(Bacou 1987). 또한 그는 그 장소에서 “어린아이와 같은 새로운 영혼"을 찾을 수 있고, 단순히 쉬는 것이 아닌 “새로운 환영(illusion)”을 위한 곳이라고 하였으며, “자연과 본능을 일깨운다”고 하였다 


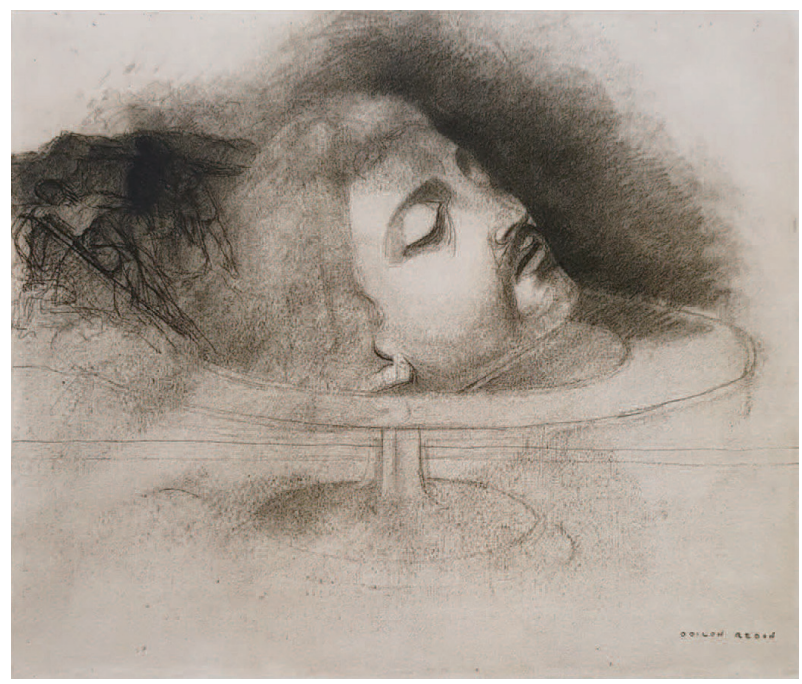

Figure 24. Head of Saint John the Baptist after Andreas Solario (1868), Graphite and black conte crayon, $34 * 28.8 \mathrm{~cm}$, The Woodner family collection.

(Druick 등 1994). 이를 무의식적 관점으로 이해하자면, 페 일레버드에서 르동은 어린 아이와 같은 위치로 퇴행됨과 동 시에 다양한 환상들을 경험한다는 뜻이다.

위 내용들을 종합하여 정리하면, 르동에게 특별한 공간인 페일레버드는 버려짐의 상처와 고통이 있지만, 어머니와 아 버지 대상, 또는 이를 대체하는 여러 무의식적 환상과 실제 경험이 내포된 다층적인 공간이며 동시에 르동의 내면 구조 와 상응하는 장소이다. 따라서 '나'를 찾기 위해서, 나와 관계 된 중요 대상을 찾기 위해서 나와 관련된 무의식적 환상이 가득한 그 공간으로 갈 수밖에 없을 것이다.

\section{르동의 자기 표상: 잘려진 머리}

르동에게 '잘려진 머리' 주제는 어느 특정 시기에 나타나 평생 반복된 주제이다. 특징적인 것은 이 잘려진 머리는 르 동의 삶에 따라 점점 변형되어 나타난다는 것이다. 그 변화 과정은 뒤의 논문에서 좀 더 자세히 다루겠지만, 잘려진 머 리는 전 회화 과정에서 약한 팔다리가 생기거나 몸이 자라는 모습으로 점점 성장한다는 것이다. 또한 이 잘려진 머리는 앞서 설명한 르동의 버려진 아이, 아버지와 어머니 대상과의 무의식적인 역동에 민감하게 반응한다는 점에서 흥미롭다.

그가 처음 잘려진 머리를 그린 것은 1868년에 화가 $\mathrm{An}-$ drea Solario의 Head of Saint John Baptist ${ }^{\mathrm{n}}$ 를 모사한 것이 다(Figure 24). 이 시기의 미술사적인 기록으로는 르동이 여

${ }^{n}$ 선지자인 세례 요한의 죽음 이야기는 이전부터 회화로 많이 다루어 졌다. 요한은 당시 지배자인 헤롯이 동생의 부인과 결혼함을 비판하 다가 그 부인인 헤로디아의 미움을 받았고, 자신의 딸인 살로메를 이용하여 요한의 목을 요구하여 죽였다.

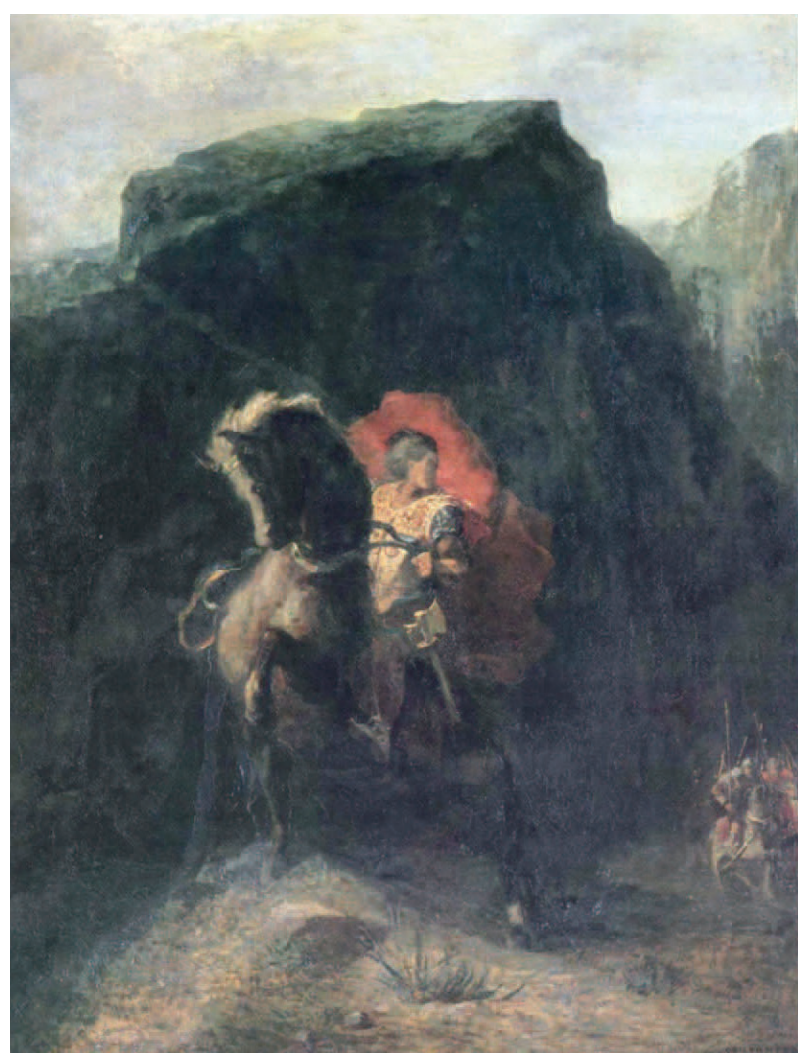

Figure 25. Roland de Roncevaux (1868-1869), Oil on canvas, 61* $48 \mathrm{~cm}$. Musee de Orsay.

성에 대한 사적인 언급한 적은 거의 없다고 한다(Druick등 1994). 따라서 위에서 분석을 했듯 무의식적 관점에서의 회 화 분석을 통해 그 역동을 짐작할 수밖에 없다. 흥미롭게도 그가 잘려진 머리를 그린 시기는 어머니 대상과 관련된 여 러 과정이나 롤랑 신화의 승리를 그렸던 때와 겹친다. 1866 년에 그린 Figure 5부터 1868년 Figure 8까지 이어지는 어머 니 대상과의 합일되는 환상(merging fantasy), 즉 어머니를 소유하는 환상과 함께 롤랑 이야기에서 주인공에 자신을 동 일시하여 승리를 소망한(Figure 25) 르동의 내면 세계는 무 의식에 존재하는 아버지 대상, 처벌하는 초자아를 피할 수 없는 것이다. 이는 어쩌면 르동의 내면에서 일어나는 오이디 푸스 갈등으로 이상화한 어머니 대상을 소유함과 동시에 일 어나는 필연적인 아버지 대상의 처벌-거세-의 전형적인 이야기일지도 모른다. 이와 유사한 역동을 그린 대표적인 예 는 카라바조의 회화에서 보인다(Figure 26). 생애 대부분을 살인과 폭력으로 사회적 물의를 일으켰던 천재 화가는 다윗 에 의해 잘려진 골리앗 머리의 얼굴을 자신의 얼굴로 그렸다. 이는 내면화된 초자아 처벌의 역동을 잘 드러낸 그림이다.

이러한 흐름에서 1868년 작 Figure 7, 8에서 보이는 여인이 '손을 뻗치는 모습'에 대한 분석을 할 수 있을 것 같다. 이 그 림을 시작하기 전 르동은 1865년 작 Figure 27에서 프로메 
테우스에 대한 신화를 도입한다. 인간을 위해 불을 훔친 죄 로 제우스로부터 독수리에게 평생 간을 쪼여 먹히는 형벌을 받은 이야기는 권력자에 대항한 처벌의 상징으로 여겨졌고, 많은 회화나 소설에서 다뤄졌다. 이 스케치에서 주인공 프로 메테우스-르동 은 처벌의 대상인 독수리를 향하여 '손을

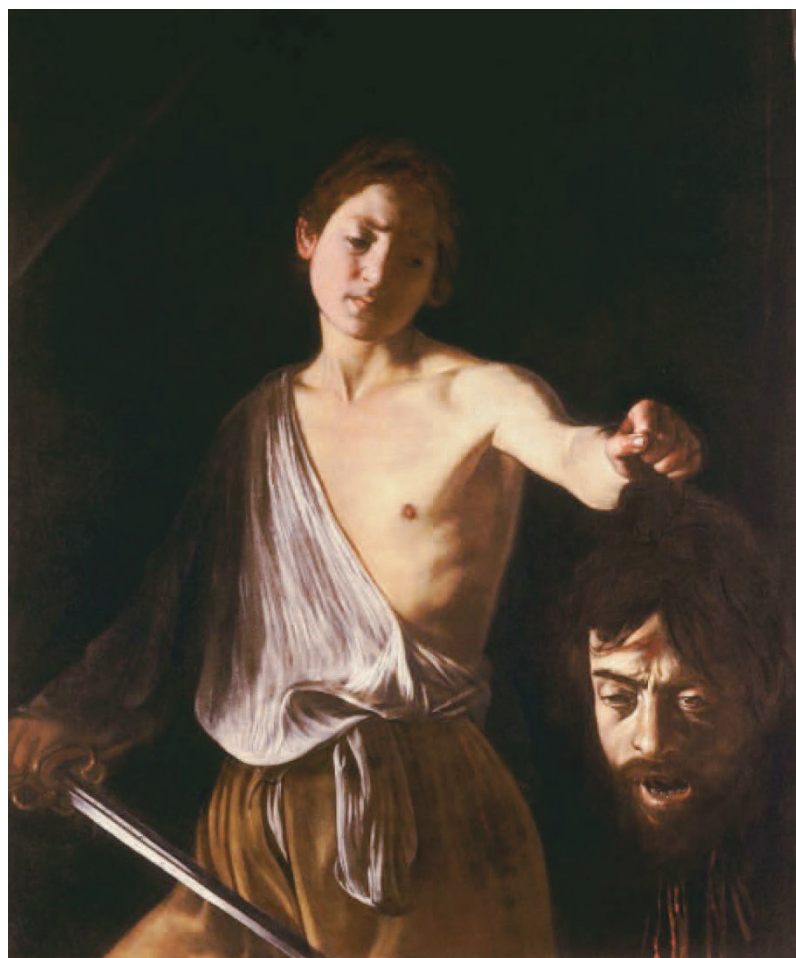

Figure 26. Caravaggio (1571-1610) David with the Head of Goliath (1605/6), Oil on canvas, $125 * 100 \mathrm{~cm}$, Galleria Borghese.
뻗치며' 반응하고 있다. 이 손을 뻗친 주인공의 행위는 뒤의 Figure 7,8 에서 다시 사용되어 어머니를 소유한 대가에 대 하여 초자아 대상의 처벌에 반응하는 모습으로 반복되어 사 용되는 것이다.

'잘려진 머리' 회화는 1874년 아버지의 죽음, 미래 부인이

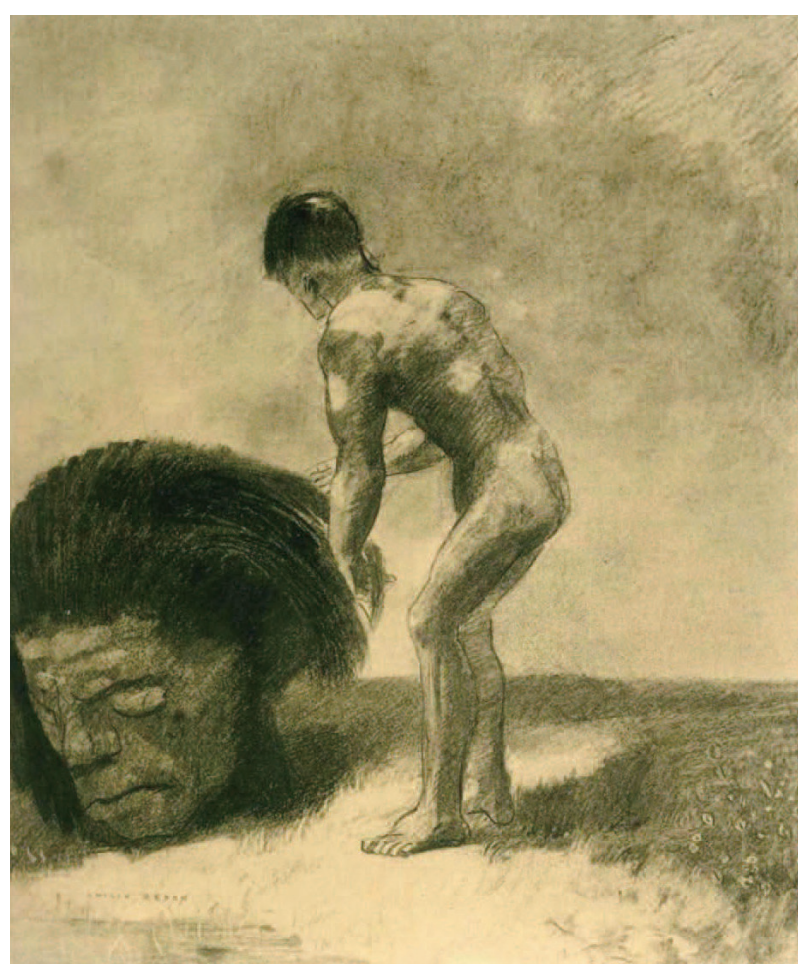

Figure 28. Primitive Being (1875), Charcoal, $44 * 36 \mathrm{~cm}$, Mar de Montebello.

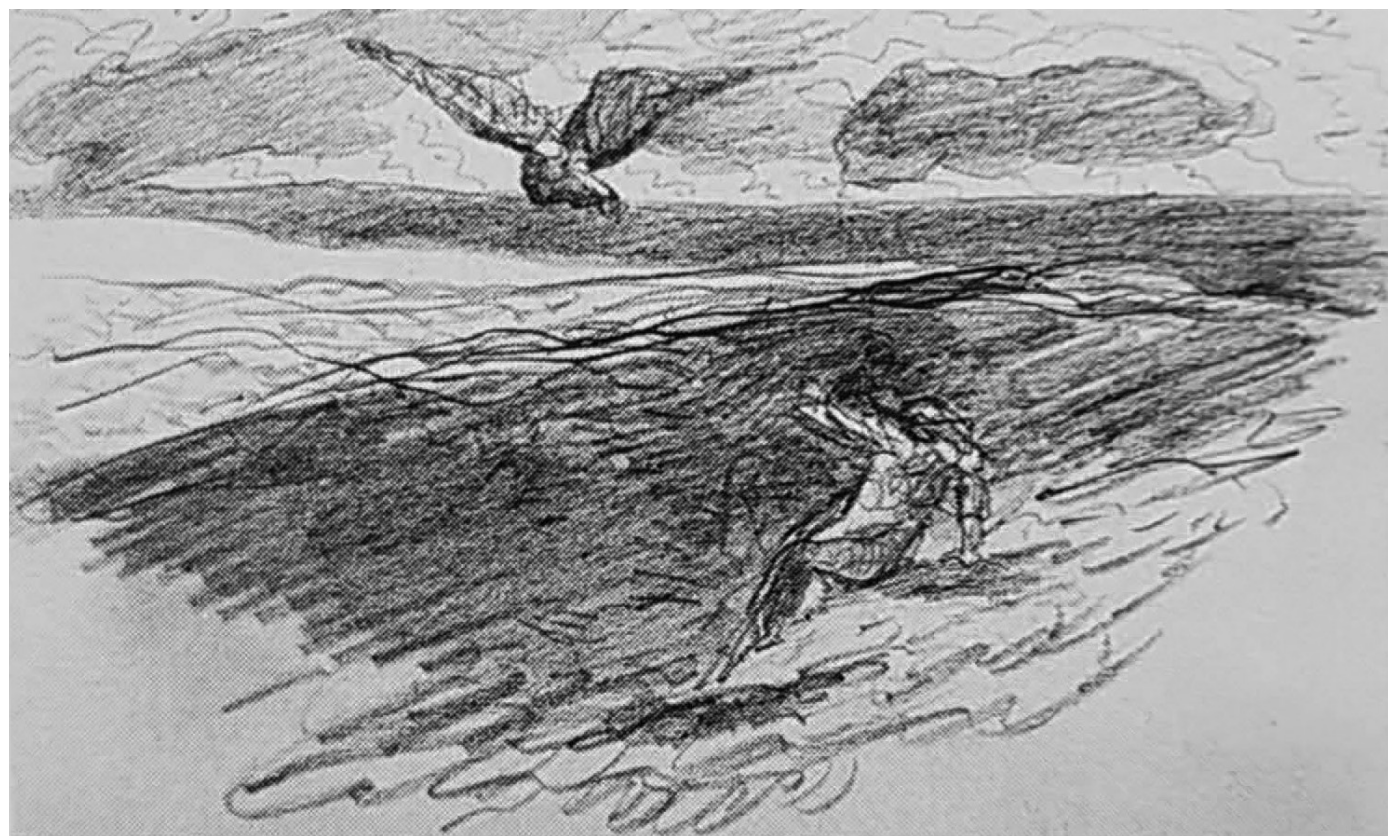

Figure 27. Prometheus and the Eagle, from Sketchbook II (1865), Graphite, 10*16.2 cm, Musee du Louvre. 
될 카미유를 만난 후에 다시 반복된다(Figure 28). 이는 앞서 설명한 Figure 24와 무의식적 역동이 서로 상응한다. 벌거벗 은 아이가 아버지로 상징되는 험상궃은 거인의 잘린 머리를 만지고 있다. 이 잘려진 머리는 아버지의 죽음과 평행하는 의미에서 르동의 분노에 의해 잘린 아버지 머리로 짐작되지 만, 정신분석적인 관점에서는 이 아버지의 잘려진 머리는 바 로 ‘내재화'된 르동의 머리인 것이다. 이러한 역동과 유사한 표현은 다름 아닌 위에서 설명했던 카라바조의 Figure 26이 다. 이러한 과정을 간단한 임상적인 예로 자세히 설명할 수 있다. 임상에서 관찰되듯 아버지를 향한 분노는 결국 거세와 죄책감과 같은 자기 처벌로 이어져 마치 '아버지를 향한 분 노가 나를 향한 분노'로 느껴지는 것이다. 이 무의식적 흐름 은 1878년의 Figure 29로 이어져 소년과 성인이 섞인 중간 단계의 잘려진 머리로 표현된다. 작은 날개를 가진 불안정한 머리는 바다 위에 불안정하게 돛단배를 보며 어디로 가는 듯하다. 이 회화는 드디어 본문 첫 시작의 회화(Figure 1)로 향하게 된다. 불안정한 머리는 아이의 잘려진 머리와 눈 모 양의 기구로 변하여 '안정적'인 항해를 하는 것이다.

\section{페일레버드로 향하여(Figure 1)}

저자는 본문을 시작하면서 르동이 눈 모양의 기구를 그린 Figure 1 이후 검은색만을 사용한 이유에 대하여 무의식적 역동이 영향을 주었을 것이라 가정하였고, 이에 대한 근거들 을 위에서 설명하였다. Figure 1과 연결을 위해 앞 내용을 간단히 정리하면 다음과 같다. 페일레버드는 르동에게 무의 식적 어머니 대상이 존재하고, 아버지와의 기억이 가득 찬 공 간이다. 르동은 마치 루소가 정글 연작을 통해 강박적으로 어 머니 대상을 복원했듯이(Lee와 Yoon 2021), 르동의 무의식은 어머니 대상에 대한 환상이 가득한 페일레버드 공간을 지향 한다. 하지만 의존적인 르동은 혼자 페일레버드로 갈 수 없 다. 그의 삶 전반에서 그랬듯 아버지가 필요한 것이다. 아버 지에 의존적인 모습과 처벌적인 아버지 대상의 존재는 거세 된 머리로 타협 형성된다. 그는 아마도 어머니 뱃속의 르동을 이끌고 바다를 건넜던 아버지의 이야기가 영향을 주어 Figure 29 를 그린 듯하다. 목 부위 작은 날개가 있는 머리는 마치 ‘아버지가 타고 온 배'를 보면서 이동한다. 하지만 작은 날개 는 불안정하다. 따라서 당시 유행했던 애드벌룬인 기구를 적 용한다(Figure 1). 기구를 이용하여 그는-환상을 품었던어린 아이의 잘려진 머리가 되었고, 안전하게 그가 바라는 공 간으로 갈 수 있다. 아버지의 '구름' 이미지는 역시 기구로 변 형되어 그의 아버지 대상의 의존성을 만족시킨다. 또 하나 언급할 사항은 기구의 모양이 '시선이 위로 향하는 안구의 형태'이라는 것이다. 이는 아마도 초자아의 대상의 감시의

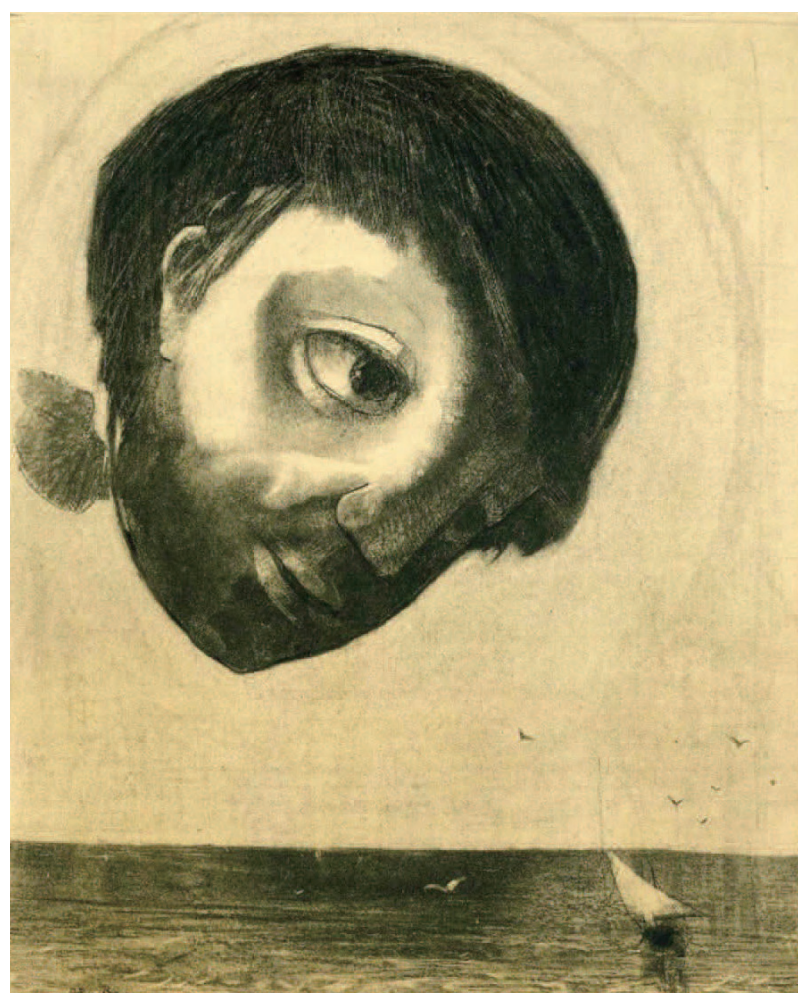

Figure 29. Guardian Spirit of the Waters (1878), Charcoal, 46.6*37.6 $\mathrm{cm}$, The Art institute of Chicago.

시선을 의미하며, 위의 이미지에 꿈과 같은 압축(condensation)의 기전이 작용한 듯하다. 또한 그 시선이 위를 향했다 는 점은 어머니 대상과 이어진 리비도적 환상의 공간인 페일 레버드로 가기 위해서는 어쩌면 당연한 이미지적 타협인 것 같다. 이 이미지는 바로 뒤의 작업에 유사하게 사용됨으로 그 근거가 확인이 된다(Figure 30). 그의 첫 본격적인 석판화 집 연작 '꿈 속에서(Dans le Reve)'의 8번째 작품으로 남녀 가 어둠에서 손을 잡고 도망치듯 가는데 그 '초자아의 시선' 은 위를 향해 있다.

르동은 그의 주요 대상과의 무의식적 환상이 다층적으로 존재하는 검은 공간-페일레버드-에 여러 무의식적 역동 을 경험하면서 지향하였고, 그 과정들을 회화로 표현하였다. 르동은 이후 이 검은색의 세계에서 무의식적 '나'를 다양한 환상을 시각화함으로 표현하였다. 이 부분은 차후 논문을 통 해 밝혀질 것이다.

\section{결 론}

이 글에서 저자는 르동이 검은색으로 본격적인 작업을 하 기 전의 삶과 회화를 분석하여 '검은색의 형성 과정'에서 무의 식적 역동이 의미 있는 위치에 있음을 설명하였다. Figure 1 은 르동이 자신의 고향 페일레버드로 향하기 위해 무의식적 


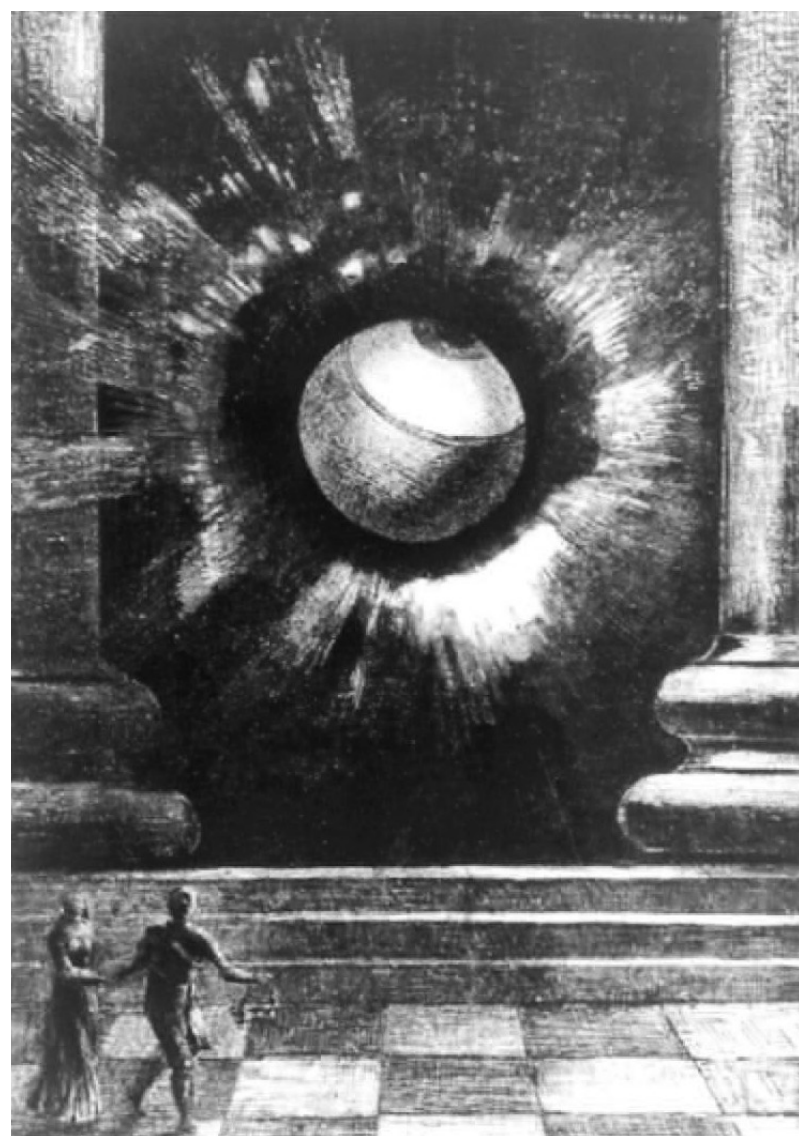

Figure 30. Dans le Reve (In Dreams); Vision, plate 8 (1879), Album with cover frontispiece and eight plates, Lithographs, The Art Institution of Chicago.

역동이 타협한 모습이며, 이후 르동은 자신을 표상하는 검은 공간에서 다양한 환상들을 시각적으로 펼친다. 물론 이러한 무의식적 역동의 영향은 미술사가들이 밝혀낸 여러 시각들 과 서로 상보하는 관계를 가진다. 간략하게 정리하면 다음과 같다. 페일레버드의 실제 모습, 스승 브레댕, 클라보의 영향, 어릴 때 그렸던 목탄 작업, 다빈치나 렘브란트의 영향, 당시 정치나 사회 문화적인 영향 등이다. 이러한 연구들과 함께 저자가 분석한 그의 회화 기저에 있는 개별적인 내러티브무의식적 환상-은 그의 회화 양식이나 공간에 의미 있는 위치를 차지한다(Table 1). 르동의 검은 공간은 앞의 분석대 로 다양한 의식/무의식적 경험과 역동의 결과로 회화의 공 간 형성에 개별성을 부여한다. 특히 외부 현실의 공간이 아 닌 내면 세계를 위한 무대를 시각화했다는 점은 모더니즘 회화에서 중요한 발전을 시사한다. 또한 그의 회화 양식과 오브제는 그의 검은 회화 분석에서 더 명확하게 분석되겠지 만, 꿈의 역동인 상징, 압축, 전치 등 꿈의 작업 방식이 자유 롭게 사용된다는 점에서 개별적인 양식 형성에 무의식적 역 동의 중요성을 말하는 것이다.

저자의 이 논문은 한계가 있다. 첫째, 저자는 르동의 회화
가 꿈의 해석과 관련이 있다고 주장하였지만, 그 해석 과정 에서 재료의 출처 및 연상을 많이 다루지 못했다. 이 부분에 대해서는 임상 과정과 예술 분석 상황의 차이가 있고, 지면 의 한계가 있다는 것이다. 따라서 위 부족한 점은 저자에게 위 한계를 매울 수 있는 훌륭한 분석 자료를 제공해 준 미술 사학자의 책(Druick 등 1994)을 소개함으로 채울 수 있을 것 같다. 둘째, 저자의 분석 방법인 작가의 삶과 회화의 무의식 적 연결에 대한 의문이다. 이는 모든 회화 분석에서 고려해 야 할 제한점으로 생각되며, 그 한계 자체가 앞으로 지속적 인 연구를 통해 보충해야 할 동기인 듯하다.

르동의 본 연구는 앞으로 이어질 르동 논문의 길을 열어 주는 역할을 함과 동시에 저자가 분석하고 있는 다른 작가 들처럼 임상에서 경험하는 무의식이 회화에 어떻게 표현되 는지 확인하게 될 것이다. 이러한 연구를 통해 인간 전체의 경계를 시각적으로 무한히 확장하고 있는 예술에 무의식의 경험이 중요한 이해의 틀이 될 가능성을 제시할 것이다.

\section{Acknowledgments \\ None}

\section{Conflicts of Interest}

The authors have no potential conflicts of interest to disclose

\section{Author Contributions}

Conceptualization: all authors. Investigation: Lee Hyun Kwon. Methodology: Lee Hyun Kwon. Project administration: Lee Hyun Kwon. Writing — original draft: Lee Hyun Kwon. Writing - review $\&$ editing: all authors.

\section{ORCID iD}

Hyun Kwon Lee https://orcid.org/0000-0002-6193-2552

\section{REFERENCES}

Bacou R. Odilon Redon: pastel. New York: George Braziller, Inc;1987. p.7-21.

Druick DW, Leeman F, Groom G, Sharp P, Stevens M, Stratis H, et al. Odilon Redon: prince of dreams, 1840-1916. Chicago: Art Institute of Chicago;1994. p.13-117.

Freud S. The interpretation of dreams. London: Hogarth Press;1900. p.1626.

Freud S. Leonardo da Vinci: a memory of his childhood. SE 11. London: Hogarth Press;1910. p.57-138.

Gibson M. Redon. Koln: Taschen GmbH;2017. p.6-91.

Han SH. A study of 'noir' in the prints of Odilon Redon. Journal of the Association of Western Art History 1995;7:171-174.

Kim HJ. Integrated spirituality in the works of Odilon Redon [dissertation]. Seoul: Ewha Woman University;2002. p.80-88.

Lee HK, Yoon HR. Study for artist Henri Rousseau in the perspective of the unconscious. J Korean Psychoanalysis Society;2021. p.50-61.

Redon O. To myself. Jacob M, Wasserman JL, trans. New York: George Braziller, Inc;1986. p.7-54.

Werner A. The Graphic works of Odilon Redon. Unites States: Dover Publication;2017. p.10.

Wilson E Jr. Revue Française de psychanalyse. XLII, 1978. Psychoanal Q 1982;51:668-669. 